EUROPEAN UNIVERSITY INSTITUTE, FLORENCE

DEPARTMENT OF LAW

EUI Working Paper LAW No. 2004/10

Justice as Conflict Resolution:

Proliferation, Fragmentation and Decentralization

of Dispute Settlement in International Trade

ERNST-ULRICH PETERSMANN 
All rights reserved.

No part of this paper may be reproduced in any form without permission of the author(s)

(C) 2004 Ernst-Ulrich Petersmann

Published in Italy in September 2004

European University Institute

Badia Fiesolana

I - 50016 San Domenico (FI)

Italy

www.iue.it 


\title{
JUSTICE AS CONFLICT RESOLUTION: PROLIFERATION, FRAGMENTATION AND DECENTRALIZATION OF DISPUTE SETTLEMENT IN INTERNATIONAL TRADE
}

\begin{abstract}
Prevention and resolution of conflicts on the basis of agreed rules and just procedures is a common objective of private and public, national and international law (chapter I). The diversity of national and international dispute settlement for a and procedures sets incentives for "forum shopping" and "rules shopping" not only in private commercial law (chapter II), but increasingly also in public international economic law (chapter III). Effective litigation strategies must examine the respective (dis)advantages of Alternative Dispute Resolution (ADR) methods and fora (chapter IV). ADR options are increasingly important also for various categories of dispute settlement proceedings in the World Trade Organization (WTO, chapter V). Optimal dispute prevention and dispute settlement strategies require distinguishing the different categories of international trade disputes according to their underlying conflicts of interests, promoting legal consistency between international and domestic dispute settlement proceedings, and "decentralizing" certain kinds of international economic disputes over private rights (chapter VI). Jurisdictional competition, forum shopping, rules shopping, and the increasing number of mutually conflicting judgments by national and international courts call for international cooperation among judges so as to promote more respect for international law through transnational, judicial networks (chapter VII).
\end{abstract}

Prof. Dr. Ernst-Ulrich Petersmann ${ }^{*}$

\section{Justice as Conflict Resolution based on Equal Basic Rights}

In a world of individual and social diversity and of unlimited demand for limited resources and limited knowledge, the rational egoism and limited altruism of individuals ${ }^{1}$ makes conflicts of interests inevitable. Every human being is confronted, throughout one's life, with this need to prevent or settle internal conflicts (e.g. among the passions and rationality inside the minds of individuals) as well as external conflicts (e.g. among self-interested individuals in families, cities and other social groups). Just as individual rationality requires "examining", "reviewing" and impartially "judging" contested facts and contrary arguments in one's own mind, so does social rationality require fair procedures and "just" rules which "justify" peaceful prevention or settlement of disputes in a manner respecting equal basic rights of the parties to the dispute (e.g. audi alteram partem: hear the other side). Rational attempts at elaborating such principles and procedures for the peaceful prevention or resolution of conflicts are common characteristic of national and international legal systems.

Since Plato's Republic and Aristotle's Politics, this dependence of "just" conflict resolution on adversary reasoning and self-imposed rules - such as moral principles for the internal peace of individuals, and constitutional rules for democratic city republics - has remained the central theme of legal philosophy. ${ }^{2}$ Whereas Plato and Aristotle defined social

* Joint chair Professor of International and European Law at the European University Institute, and director of the Transatlantic Program of the Robert Schuman Centre for Advanced Studies, in Florence (Italy). Former legal adviser in the German Ministry of Economic Affairs, GATT and the WTO, and chairman, member or secretary of numerous GATT/WTO dispute settlement panels. This contribution is an updated summary of my lectures at the Hague Academy of International Law in June 2000.

${ }^{1}$ On the concept of the individual in social sciences see: J.B.Davis, The Theory of the Individual in Economics, 2003.

${ }^{2}$ On the ancient Greek concept of "law as participation in the idea of justice", see C.J.Friedrich, The Philosophy of Law in Historical Perspective, 1963, chapters II and XX. 
justice as harmony under the governance of reason and perceived psychological and social conflicts as evils, modern legal, political and economic theories acknowledge the inevitability and normality of conflicts and the impossibility of substantive harmony in extended, antagonistic societies. ${ }^{3}$ Respect for individual freedom entails that internal and social conflicts are not necessarily signs of a vice. Respect for the "moral imperative" of protecting maximum equal freedoms further implies that prevention and settlement of disputes should focus not only on the rights and interests of the parties to the dispute, but should remain consistent with the progressive extension of "democratic peace" based on universalizable rules of justice. ${ }^{4}$ For centuries, international trade law has been evolving from local, national and bilateral towards multilateral trade regulation and dispute settlement systems so as to better protect the rational long-term interests of individuals and states (e.g. in rule of law, open markets, consumer welfare) against their often conflicting short-term interests (e.g. in "efficient breaches" of contractual obligations). The legal and institutional changes also influence the culture and outcome of negotiations and politics, for example by promoting "principled bargaining" and "deliberative politics" rather than "positional bargaining", rule-oriented rather than poweroriented dispute settlement procedures ${ }^{6}$, and judicial protection of general citizen interests rather than of bureaucratic self-interests and powerful group interests.

Prior to the constitutional recognition of human rights, theories of justice tended to focus on procedural justice, such as fair procedures and requirements to respect reasonableness and good faith (e.g. pacta sunt servanda), notwithstanding the manifold poweroriented limitations of legal rules since antiquity (e.g. discrimination of women, slaves, citizens without property). Public international law, like national legal systems, evolved from poweroriented rules (e.g. as regards state sovereignty) which often attached more importance to power (e.g. effective government control over a population in a limited territory) than to democratic legitimacy. To the extent that conflicts reflect such struggles for power rather than a search for mutually acceptable rules, rational procedures and peaceful conflict prevention may fail. The today universal recognition of "inalienable" human rights entails that justice must be defined more comprehensively in terms of procedural as well as substantive human rights and constitutional rights of individuals. ${ }^{8}$ The human rights obligations of UN member states to respect, protect and promote human rights and "democratic peace" in all government activities challenge some of the power-oriented premises of state-centered rules; they require to review, from a human rights perspective, the traditional approaches to international dispute prevention (e.g. by state-centered rule-making and rule-implementation) and dispute settlement (e.g. by negotiations and third-party adjudication among governments). In European economic integration law, the Courts of Justice of the European Community (EC), of the European Free Trade Area (EFTA) and national courts recognize and protect human rights and market

${ }^{3}$ On such a "philosophy of conflict" defining justice as fair procedures for conflict resolution, see e.g. S.Hampshire, Justice is Conflict, 2001, chapter I. For a different concept using "preventive law", based on the analogy with preventive medicine, for preventing the contagious "disease of litigation" that may lead its victims financially and emotionally weakened, see e.g.: L.M.Brown, Manual of Preventive Law, 1950.

${ }^{4}$ On the Kantian "moral imperative", and the Kantian theories of antagonistic human behavior and "just rules" leading to ever more precise, national and international constitutional guarantees of equal freedoms, see A.D.Rosen, Kant's Theory of Justice, 1993.

${ }^{5}$ On negotiation theories and political theories explaining why institutional rules can improve the quality and output of negotiations and of political discourse, see e.g.: R.Fisher/W.Ury, Getting to Yes. Negotiating Agreement without Giving In, $2^{\text {nd }}$ ed 1991; J.Steiner et alii (eds), Deliberative Politics, 2004.

${ }^{6}$ Cf. e.g. E.U.Petersmann, The GATT/WTO Dispute Settlement System, 1997, at 66-70.

${ }^{7}$ Cf. e.g. T.M.Franck, Fairness in International Law and Institutions, 1995.

${ }^{8}$ See e.g. A.Buchanan, Justice, Legitimacy and Self-Determination. Moral Foundations for International Law, 2004; E.U.Petersmann, Theories of Justice, Human Rights and the Constitution of International Markets, EUI Working Papers Law No. 2003/17. 
freedoms against national and intergovernmental restrictions also in the economic sphere. ${ }^{9}$ In intergovernmental procedures for the settlement of economic disputes, however, the procedural and substantive rules for preventing or resolving disputes continue to focus on equal rights of states rather than on individual rights. Such differences in the applicable rules and dispute settlement procedures, and the often overlapping jurisdiction of alternative dispute settlement fora (e.g. for disputes over intellectual property rights), favor "forum shopping", "rules shopping" and mutually inconsistent judgments (e.g. if national courts disregard intergovernmental rules), which can give rise to complex problems for national and international courts (see below chapters II and III).

The human right of access to justice is today almost universally recognized ${ }^{10}$ and reflects the worldwide recognition of the need for fairness and justice in dispute settlement procedures at home and abroad. In European integration law, individual legal and judicial remedies (e.g. based on EU law and the European Convention on Human Rights) have been progressively extended to protect not only civil and political, but also economic and social rights and "market freedoms" against national and intergovernmental restrictions. The WTO Agreement includes less comprehensive, legal and judicial guarantees of individual access by traders, producers and other economic operators to domestic courts. ${ }^{11}$ Like the domestic implementation of WTO rules, the legal and judicial guarantees of individual access to courts (e.g. vis-à-vis trade restrictions) continue to differ from country to country depending on its respective constitutional and legal traditions. In the EC and the US, domestic courts hardly ever apply and enforce the international WTO obligations of the country concerned ${ }^{12}$; in line with the mercantilist traditions of GATT and WTO negotiations, only export industries are being granted (e.g. under Section 301 of the US Trade Act and the corresponding Trade Barriers Regulation of the EC) legal and judicial remedies against violations of WTO rules by foreign governments ${ }^{13}$, without equal legal remedies against the same violations of WTO obligations by their own governments. The variety of national and international rules and procedures for the settlement of international economic disputes has led to an increasing proliferation and fragmentation of dispute settlement fora and jurisprudence in international trade law. Dealing with conflicting legal claims, adversary arguments, "forum shopping" and "rules shopping" not only by governments, but also by individual producers, investors, traders and other economic operators in a manner promoting justice to be done, and seen to be done, remains a fundamental challenge in international economic law.

\footnotetext{
${ }^{9}$ See e.g. the references to the relevant jurisprudence in the chapters on "access to justice", the "internal market" and "remedies" in: S.Peers/A.Ward (eds), The EU Charter of Fundamental Rights, 2004.

${ }^{10}$ In addition to the contribution by A.Ward, Access to Justice, in Peers/Ward (above note 10) see also: C.Harlow, Access to Justice as a Human Right, in: P.Alston et alii (eds), The EU and Human Rights, 1999.

${ }^{11}$ E.g. in the GATT (Article X), the WTO Agreement on Antidumping (Article 13), the Agreement on Customs Valuation (Article 11), the Agreement on Subsidies (Article 23), the Agreement on Pre-shipment Inspection (Article 4), the GATS (Article VI), the TRIPS Agreement (e.g. Articles 41-50,59) and the Agreement on Government Procurement (Article XX), cf. Petersmann (note 6), at 194-196.

${ }^{12}$ Cf. the country-studies in J.Jackson/A.Sykes (eds), Implementing the Uruguay Round Agreements, 1997, and the comparative studies of the more recent jurisprudence by EC and US courts in the contributions by Barcelo and Petersmann to: J.J.Barcelo/H.Corbett (eds), Role of the WTO System in the World Economy, 2005.

${ }^{13}$ Cf. C.Tomas Garcia Molyneux, Domestic Structures and International Trade. The Unfair Trade Instruments of the United States and EU, 2001.
} 


\section{II. "Forum Shopping" and "Rules Shopping" in Private and Public Trade Law: Common Problems}

For centuries, the demand for predictability and legal certainty in private commerce (ubi commercium, ibi ius) has been a driving force for the emergence of commercial customs (lex mercatoria) and institutions (like arbitration) for the prevention and settlement of commercial disputes. Even though the particular dispute settlement procedures and institutions vary immensely in different places and legal contexts (e.g. in Anglo-Saxon or civil law countries based on Roman law), and sometimes continue to reflect struggles for power (e.g. in case of judicial self-restraint vis-à-vis "political questions"), some of the diverse legal and judicial traditions appear to merge slowly in transnational arbitration and other dispute settlement practices. The steady expansion of the global division of labor entails ever more international disputes over transnational private economic activities (e.g. commercial contracts, non-contractual product liability) and government regulation of economic transactions. The more countries are involved in "international production" and trade, the more concurrent jurisdictions may exist for settling disputes concerning international economic transactions. Due to the diversity of national laws, procedures and judicial systems, the outcome of private transnational litigation - and the applicable procedures, substantive law, speed and legal costs are often influenced by the choice of the venue in which the litigation is to take place.

The complainant may choose a jurisdiction in order to benefit from the procedural advantages of the chosen forum (e.g. low filing fees, possibility of class actions, pre-trial discovery, jury trials, large damages awards, non-recovery of costs rule in US courts). The particular procedures may also influence the application of the substantive domestic or foreign law and the outcome of the dispute. The jurisdiction chosen by the complainant may be contested by the defendant who may request to stay the proceedings, apply for "anti-suit injunctions", or submit counter-claims to a different jurisdiction. The burgeoning of "international law firms" and of multinational companies with offices and legal expertise in many countries facilitate transnational litigation strategies. In case of different concurrent jurisdictions, court battles over the most convenient jurisdiction, against "exorbitant jurisdiction", over abusive "forum shopping" and "rules shopping" have become ever more frequent in private international litigation because they often influence the outcome of the dispute. ${ }^{14}$ Courts increasingly respect forum selection agreements if they reflect the free will of the parties and are neither unfair nor unreasonable nor inconsistent with the public policy in the jurisdiction of a competent court. Governments have facilitated forum selection agreements by means of international agreements on the allocation of jurisdiction, on the mutual recognition and enforcement of foreign civil judgments and arbitral awards, and by codifying legal criteria for the limitation of abusive forum shopping and for determining the "natural forum" or "most appropriate forum" with which the dispute has the closest and most real connection. ${ }^{15}$

In public international trade law, problems of "forum shopping" and "rules shopping" emerged as a result of the 1979 Tokyo Round Agreements which offered special dispute settlement procedures and substantive rules different from those of the General Agreement on Tariffs and Trade (GATT) of 1947. ${ }^{16}$ These problems were largely overcome by legally integrating and coordinating - in the substantive and dispute settlement rules of the WTO - the

\footnotetext{
${ }^{14}$ Cf. A.Bell, Forum Shopping and Venue in Transnational Litigation, 2003; W.W.Park, International Forum Selection, 1995.

${ }^{15}$ Cf. e.g. Y.Shany, The Competing Jurisdictions of International Courts and Tribunals, 2003, chapter 4.1 .

${ }^{16}$ For a list of 24 dispute settlement proceedings under the Tokyo Round Agreements on Subsidies, Antidumping and Government Procurement see: E.U.Petersmann (note 6), 271-284.
} 
various multilateral trade agreements annexed to the 1995 WTO Agreement and covered by its Dispute Settlement Understanding (DSU), notwithstanding the recognition of "special or additional rules and procedures contained in the covered agreements" as listed in Appendix 2 to the DSU. ${ }^{17}$

Outside WTO law, most international judicial bodies operate in "splendid isolation" without explicit regulation of the jurisdictional interaction between international courts and with little, if any, regard to the jurisprudence of other international tribunals. While WTO dispute settlement bodies cite judgments of the International Court of Justice (ICJ) frequently, the EC Court of Justice (ECJ) refers only rarely to decisions of other international courts; the ICJ has hardly ever cited decisions of international tribunals other than its predecessor, the Permanent Court of International Justice. Whereas forum shopping and multiple litigation have become frequent in human rights law ${ }^{18}$, they remain rare in most other areas of public international law. Jurisdictional clashes among international courts, and "judicial challenges" to the WTO jurisdiction (e.g. similar to the jurisdictional challenges of the EC Court by national constitutional courts in some EC member states), have so far been avoided.

The citizen-oriented approaches of European Courts, the ICJ's state-centered approach, and the openness of the WTO dispute settlement system to non-governmental organizations (e.g. regarding submission of amicus curiae briefs), other non-state actors (like Hong Kong, Taiwan) and intergovernmental organizations (like the EC) reflect the autonomy and diverse preferences of governments. "Judicial governance" (e.g. by the EC Court, the EFTA Court and the European Court of Human Rights) on the basis of agreed international rules has become accepted inside Europe, but continues to be often opposed in state-centered and power-oriented worldwide organizations, where the scope of compulsory jurisdiction (e.g. of the ICJ) remains much more restricted. For instance, while the US Executive Branch has largely implemented the so far (July 2004) 17 adverse WTO dispute settlement findings against administrative US trade restrictions, the US Congress has to date refused - in the 6 WTO disputes where US federal laws were found to be inconsistent with WTO obligations - to bring the US legislation into conformity with the US' obligations under WTO law. ${ }^{19}$ Whereas capital-exporting countries (like the US) have tended to favor investor-state arbitration as long as such arbitration was directed against capital-importing countries, the ICSID arbitration award of 23 June 2003 in the case Loewen Group v. United States has provoked hostile US criticism (e.g. in US media and by US non-governmental organizations) that an international arbitral tribunal had dared to criticize the "unfairness" of US court procedures (concerning a Mississipi jury award of $\$ 500$ million damages against a foreign investor), even though - in the final court orders - the court found it lacked jurisdiction under the applicable rules of the North American Free Trade Agreement (NAFTA) and refused to correct the observed "miscarriage of justice." 20

\footnotetext{
${ }^{17}$ For details see Petersmann (note 6), 177-182.

${ }^{18}$ Cf. L.R.Helfer, Forum Shopping for Human Rights, in: University of Pennsylvania Law Review 1999, 285 .

${ }^{19}$ The 6 WTO dispute settlement rulings requiring action by the US Congress relate to the US legislation on Foreign Sales Corporations, the 1916 US Antidumping Act, the Byrd Amendment, Section 211 of the US Appropriations Act (relating to the trademark "Havana Club"), Section 111 of the Copyright Act (relating to Irish music copyrights), and recent amendments of the Antidumping Act (relating to hot-rolled steel from Japan). For detailed references to the relevant WTO documents see: WTO document WT/DS/OV/20 (March 2004).

${ }^{20}$ The citations are from paragraphs 241 and 242 of the arbitration award (published e.g. in Journal of World Investment 2003, at 675 et seq). On the hostile US reactions to the increasing number of NAFTA arbitrations against the US see e.g. G.Aguilar Alvarez/W.W.Park, The New Face of Investment Arbitration: NAFTA Chapter 11, in: Mealey's International Arbitration Reports, January 2004, at 39,41.
} 
The diverse national and international dispute settlement procedures in private and public international trade law reveal an increasing number of common features and problems. Examples include:

(1) the increasing recourse to treaty-based international arbitration, e.g. in the WTO, under the Law of the Sea Convention, under the 1994 Energy Charter Treaty, in the NAFTA, the International Center for the Settlement of Investment Disputes (ICSID), and the International Chamber of Commerce (ICC);

(2) the frequent composition of arbitral tribunals not only by lawyers, but also by non-legal experts (e.g. in trade, banking, insurance, telecommunications and sports arbitration);

(3) challenges by non-governmental organizations (NGOs) to the confidentiality of arbitration (e.g. in NAFTA and ICSID) and of other dispute settlement proceedings (e.g. in the WTO), including requests for admission of amicus curiae briefs, private access to documents, and the right to use private legal counsels (e.g. in WTO dispute settlement proceedings) who are increasingly involved in the drafting of legal submissions by governmental complainants and defendants;

(4) the growing influence of public international law, including general principles of law (e.g. on treaty interpretation, good faith, estoppel, abuse of rights, human rights), on the applicable law in commercial arbitration, "mixed" investor-state arbitration (e.g. in the more than 100 arbitration proceedings under ICSID rules), and also in trade disputes (e.g. references to human rights in ECJ jurisprudence on trade restrictions, references to multilateral environmental agreements in WTO dispute settlement reports);

(5) the expanding scope of the "arbitrability" of private disputes (e.g. over antitrust rules and intellectual property rights) as well as of intergovernmental economic disputes which, even if formally conducted among states (e.g. in the WTO), are often initiated by private complainants (e.g. in the "Kodak/Fuji" WTO dispute over alleged anticompetitive practices in Japan, or in the "Havana Club" WTO dispute over the trade mark claims of two competing liquor companies in Europe and the US) and are carried out like "private-public partnerships" (e.g. in the conduct of WTO dispute settlement proceedings); ${ }^{21}$

(6) the judicial methods of interpreting "public policy clauses" (like Article XX GATT, Article 30 EC Treaty) by recourse to the constitutional principles and public policies in the countries involved (such as principles of necessity and proportionality of government restrictions);

(7) an increasing recognition by national and international courts of the advantages of international collaboration among judges in order to promote legal consistency of judgments by different courts;

(8) increasing recourse to alternative methods of dispute resolution (ADR), such as use of special fact-finding procedures (e.g. pursuant to Annex V of the WTO Agreement on Subsidies) and mediation in the WTO, agreed recourse to arbitrators as "facilitators", and other ADR methods in commercial arbitration, for instance in the already more than 3'000 domain name disputes under the arbitration and mediation rules of the World Intellectual Property Organization (WIPO);

(9) an increasing number of successive or parallel dispute settlement proceedings in national, regional or worldwide fora (e.g. on antidumping duties, countervailing duties, safeguard measures, EC import restrictions on bananas and genetically modified goods) with sometimes mutually incoherent rulings if national courts and regional courts (e.g.

${ }^{21}$ Cf. G.Shaffer, Defending Interests: Public-Private Partnerships in WTO Litigation, 2003. 
in the EC, EFTA, NAFTA) disregard the relevant WTO obligations of the countries concerned and such court rulings are subsequently challenged in WTO dispute settlement proceedings;

(10) concurrent and partly overlapping jurisdiction of national and international courts, which requires potential complainants to carefully examine their litigation options and litigation strategies, for example in view of the more limited legal remedies in WTO dispute settlement proceedings over intellectual property rights compared with intellectual property disputes in the ICJ, NAFTA, ICSID, WIPO arbitration or domestic courts.

\section{Ten Reasons for Increasingly Overlapping Jurisdictions and Forum Shopping in Public International Trade Law}

For a number of reasons, the above-mentioned trends and problems of "overlapping jurisdictions", "forum shopping", concurrent or successive trade disputes and related court proceedings in different fora over the same legal claims are likely to further increase also in public international trade law:

(1) The increasing number and diversity of intergovernmental WTO disputes entails increasing overlaps with prior, parallel or successive related disputes at national and regional levels. For example, parallel to the WTO dispute settlement proceedings against EC import restrictions on bananas and the EC's restrictions on biotech products, related disputes were pending before the EC Court of Justice and national courts in EC member countries. The more than 310 formal complaints notified to the WTO since 1995 up to April 2004 have led to about 90 panel reports, 61 Appellate Body reports and more than 25 arbitration awards. ${ }^{22}$ Compared with the only about 200 dispute settlement proceedings under GATT 1947 between 1948 and $1994^{23}$, the only 3 NAFTA panel proceedings pursuant to Chapter 20 during the past 10 years, and the less than 100 adversarial proceedings before the ICJ since 1946, the rapidly increasing number of WTO panel, appellate and arbitration proceedings reflects the increasingly universal WTO membership, the ever broader scope of WTO law, and the "judicialization" of dispute settlement in almost all areas of the WTO, even in highly fact-oriented areas (like the 2003 panel report on US safeguard measures on steel products which includes more than 900 pages) and in new fields of WTO law (like services trade and intellectual property rights).

(2) With the phasing-out of the various transitional WTO provisions for less-developed countries and for certain kinds of disputes (e.g. on agricultural subsidies covered by the "peace clause" in Article 13 of the WTO Agreement on Agriculture), the number of WTO disputes is likely to further increase rapidly. In terms of binding treaty obligations, precision of rules, compulsory jurisdiction of national and international (quasi)judicial dispute settlement proceedings, and the number of WTO panel, appellate and arbitration reports, WTO law is progressively evolving into the most "legalized" area of worldwide international law.

(3) The very broad scope of WTO agreements overlaps with other international agreements (such as the Paris Convention on Industrial Property, the Bern Convention for the

\footnotetext{
${ }^{22}$ Lists of these dispute settlement reports and legal analyses of these disputes are to be found in WTO document WT/DS/OV/20 and in F.Ortino/E.U.Petersmann (eds), The WTO Dispute Settlement System 19952003, 2004, at 558-573.

${ }^{23}$ Cf. Guide to GATT Law and Practice, Analytical Index Vol. 2 , WTO 1995, at 771-787.
} 
Protection of Literary and Artistic Work) which provide for different dispute settlement fora (e.g. the ICJ). For instance, in the EC-US dispute over the EC's airport noise regulations limiting the use of "hushkits" by airplanes (mainly from the US), the US chose to submit the dispute to the dispute settlement procedures of the International Civil Aviation Organization rather than to the dispute settlement procedures of the WTO Agreement on Technical Barriers to Trade or, since the EC noise regulations restricted air transport services, of the General Agreement on Trade in Services (GATS). ${ }^{24}$ The increasing number of multilateral environmental agreements (= MEAs) with trade provisions and special dispute settlement procedures ${ }^{25}$ likewise offers examples for overlapping or competing jurisdictions for the settlement of trade-related disputes inside and outside the WTO, for example in the ICJ or special dispute settlement procedures provided for in MEAs. Thus, disputes over "emission trading" under the Vienna Convention and Montreal Protocol for the protection of the ozone layer, over the sharing of benefits of pharmaceutical companies from using traditional knowledge of indigenous people protected by the UN Convention on Bio-diversity, or over trade in biotech food regulated in the Cartagena Protocol to the UN Convention on Bio-diversity, may influence the interpretation of related WTO rules and WTO dispute settlement rulings.

(4) Since the 1990s, an increasing number of new worldwide courts have been established whose jurisdiction may overlap or interact with the jurisdiction of WTO dispute settlement proceedings. For example, when Chile restricted access to its ports for European fishing vessels on the ground that they were over-fishing swordfish in the Pacific in violation of the EC's obligations under the Law of the Sea (LOS) Convention to cooperate in the conservation of marine resources, the EC requested the establishment of a WTO dispute settlement panel so as to examine the alleged violations of trade rules (e.g. GATT Article V on freedom of transit), whereas Chile submitted the dispute over the alleged violation of the environmental provisions of the LOS Convention to the International Tribunal for the Law of the Sea (ITLOS). As the LOS Convention includes explicit references to GATT rules (e.g. on subsidies), and the LOS Convention rules may be relevant for the interpretation of various WTO "exceptions", parallel or mutually relevant dispute settlement proceedings in the WTO and ITLOS may occur again.

(5) Just as WTO rules are occasionally invoked and applied in the EC Court of Justice and in dispute settlement panels set up under the NAFTA, the increasing number of regional economic courts - such as the EFTA Court, the Andean, Caribbean and Central American Courts of Justice, the MERCOSUR Permanent Court of Review, the Economic Court of the Commonwealth of Independent States (CIS Court), and the various regional economic courts in Africa, for example in the Common Market of Eastern and Southern Africa (COMESA) and in the Economic Community of West Africa ECOWAS) - are likely to interpret and apply (directly or indirectly) WTO rules or regional economic rules based on corresponding WTO provisions (e.g. GATT's free trade area and customs union rules). As the legal and judicial remedies of domestic and regional courts tend to go beyond those of WTO dispute settlement bodies (e.g. regarding reparation of injury for discriminatory takings of property rights), private

\footnotetext{
${ }^{24}$ For a case-study of this dispute see: K.W.Abbott, US-EU Disputes over Technical Barriers to Trade and the 'Hushkits' Dispute, in: E.U.Petersmann/M.Pollack (eds), Transatlantic Economic Disputes - The EU, the US and the WTO, 2003, 247-280.

${ }^{25}$ Cf. C.P.R.Romano, The Peaceful Settlement of International Environmental Disputes, 2000.
} 
economic operators adversely affected by violations of WTO rules may prefer recourse to domestic and regional courts rather than to WTO dispute settlement proceedings.

Many intergovernmental WTO disputes are triggered by complaints by private producers, investors, traders, consumer associations or other non-governmental groups. Such private complainants may prefer to submit their legal claims - e.g. over intellectual property rights protected under the WTO Agreement on Trade-Related Intellectual Property Rights (TRIPS), or over investor rights protected by "market access commitments", "national treatment commitments" or "additional commitments" under the GATS - to "mixed international arbitration" granting direct access to private complainants and enabling them to handle and control themselves their dispute, without political interference by their home governments. For example, a pharmaceutical company claiming violations of its patent rights resulting from "parallel imports" into a foreign WTO member state, or from compulsory licenses granted by a foreign WTO government, may prefer to submit its dispute to the mediation and "mixed" arbitration procedures of WIPO $^{26}$ or, in case of production and foreign investments abroad, to "mixed" arbitration under the ICSID (whose jurisdiction also includes disputes over intellectual property rights ${ }^{27}$ ) or under Chapter 11 of NAFTA. ${ }^{28}$

(7) Some WTO Agreements explicitly provide for private access to domestic courts so as to examine whether, for instance, national government procurement practices have violated the government obligations under the WTO Agreement on Government Procurement. ${ }^{29}$ Article XX of the WTO Agreement on Government Procurement is noteworthy in granting private parties direct access to national "challenge procedures" before domestic courts or other independent review bodies which must provide for prompt correction of a breach of the WTO Agreement or compensation for the loss or damages suffered. The WTO Agreement on Pre-shipment Inspection even provides for private access to private or "mixed" international arbitration inside the WTO in order to examine any violations of relevant legal obligations within very short time-limits. ${ }^{30}$

The universal recognition of human rights, and the proliferation of legal and judicial remedies against human rights violations provided for in regional and UN human rights treaties, entail that international disputes over human rights may have repercussions for the interpretation and application of WTO rules, and vice versa. For example, just as the EC Court of Justice examined trade restrictions and other economic regulations (e.g. on biotech food) in the light of human rights, including a "fundamental right to human dignity and integrity",31, so may WTO dispute settlement bodies be confronted

${ }^{26}$ On the WIPO mediation and arbitration rules which also admit "mixed" arbitration between private and state parties, see: WIPO Mediation Rules, WIPO Arbitration Rules, WIPO Expedited Arbitration Rules, WIPO 1999.

${ }^{27}$ Cf. C.Schreuer, The ICSID Convention: A Commentary, 2001.

${ }^{28}$ On the different intergovernmental dispute settlement procedures (Chapter 20), mixed arbitration procedures (Chapter 11) and private access to bi-national panel procedures for the review of final anti-dumping and countervailing duty determinations (Chapter 19) in the NAFTA Agreement see e.g. L.Ojeda/C.Azar, Course on Dispute Settlement: Regional Approaches - NAFTA, UNCTAD 2003.

${ }^{29}$ On the different intergovernmental and private-state dispute settlement procedures under the 1996 WTO Agreement on Government Procurement see: P.Gabilondo, Course on Dispute Settlement: WTO Government Procurement, UNCTAD 2003.

${ }^{30}$ The "independent review procedure" provided for in Article 4 of the WTO Agreement on PreShipment Inspection was set up under the WTO in order to benefit from legal immunity and limit legal liability for damages caused by dispute settlement rulings. To date, the procedure does not appear to have been invoked.

31 The quotation is from the EC Court judgment of 9 October 2001, Case C-377/98 Netherlands v. European Parliament and Council (nyr), at para.70. More generally on economic and social rights in the 
with references to human rights, and to corresponding government obligations to protect and promote human rights, as relevant legal context for the judicial interpretation of WTO rules in the light of universally recognized human rights. ${ }^{32}$ The various reports by the UN High Commissioner for Human Rights on the human rights implications of WTO Agreements offer many examples for the potential relevance of human rights for the interpretation of WTO rules. ${ }^{33}$ The recent EC Court judgment interpreting the customs union rules of the EC Treaty in conformity with the human rights guarantees in the European Convention on Human Rights (Articles 10 and 11 on freedom of expression and freedom of assembly) illustrates that judicial balancing of human rights and trade rules may require methodological approaches different from those of international trade law. ${ }^{34}$ Just as judgments of the European Court of Human Rights (e.g. on the right to the inviolability of the home, protection of freedom of speech in the commercial field) had implications for the judicial interpretation and application of the trade and economic provisions in the EC Treaty ${ }^{35}$, so may the caselaw of UN, regional and national human rights bodies have legal relevance for the future interpretation of WTO rules, as rightly emphasized by the UN High Commissioner for Human Rights. ${ }^{36}$

(9) WTO law may be applicable to, or provide relevant legal context for, investment disputes covered by the today more than 2100 bilateral investment treaties (= BITs) with comprehensive guarantees for intergovernmental, investor-state and national

jurisprudence of the EC Court see: T.Hervey/J.Kenner (eds), Economic and Social Rights under the EU Charter of Fundamental Rights. A Legal Perspective, 2003.

32 A computer search of references to human rights in WTO panel and Appellate Body reports indicates 10 reports (up to 2002) where parties, third parties, experts, panelists or the Appellate Body referred to human rights. In the negotiations for the WTO Ministerial Declaration of November 2001 on access to medicines and review of Article 27:3(b) of the TRIPS Agreement, the "Africa Group", for instance, referred explicitly to human rights as criteria for interpreting the TRIPS Agreement.

33 See e.g. the report of the UN High Commissioner for Human Rights on the impact of the TRIPS Agreement on human rights (E/CN.4/Sub.2/2001/13) and Resolution 2001/21 by the UN Sub-Commission on Human Rights on "Intellectual Property and Human Rights" (E/CN.4/Sub.2/RES/2001/21 of 16 August 2001).

${ }^{34}$ Cf. Schmidberger v. Austria, Case C-112/2000, in: Common Market Law Reports 2003, 1043-1092. Rather than describing the demonstration blocking road traffic on the Austrian motorway as a trade barrier contrary to Article 30 and as being justified either under Article 34 EC Treaty or as a mandatory requirement permitted by the "rule of reasonable interpretation" of Article 30 EC Treaty, the EC Court avoided these traditional trade law categories and created a new justificatory category for the protection of human rights, referring to the "wide margin of discretion" of the competent authorities regarding a "fair balance" between the common market freedoms and human rights and to the need "to determine whether the restrictions placed upon intra-Community trade are proportionate in the light of the legitimate objective pursued, namely, in the present case, the protection of fundamental rights" (para.82). Such a "fair balance" may also be required in the interpretation of WTO rules. The EC Court's balancing approach rightly implies that invocation of human rights as a justification of trade restrictions must not necessarily "trump" all trade rules designed to limit protectionist abuses (e.g. procedural WTO requirements to carry out and notify a transparent risk-assessment procedure before prohibiting the importation of hormone-fed beef).

${ }^{35}$ Cf. D.Spielmann, Human Rights Case Law in the Strasbourg and Luxembourg Courts: Conflicts, Inconsistencies and Complementarities, in: Alston/Bustelo/Heenan (eds), The EU and Human Rights, 1999, 757780. On the often broader judicial protection by human rights courts of freedom of commercial speech than by trade courts, see e.g. the judgement of the European Court of Human Rights of 25 August 1998 in Hertel v. Switzerland (published in ECHR Reports 1998 - VI) which concluded that restrictions on freedom of speech imposed under the Swiss Unfair Competition Law, and upheld by Swiss courts, were in violation of Article 10 of the European Convention on Human Rights.

${ }^{36}$ Cf. e.g. Report of the High Commissioner for Human Rights on Liberalization of Trade in Services and Human Rights, document E/CN.4/Sub.2/2002/9 (2002). 
dispute settlement proceedings. ${ }^{37}$ For instance, WTO law and WTO disputes over discrimination of foreign service suppliers, or of foreign holders of intellectual property rights, may be relevant for interpreting the national treatment obligations of host states in related investment disputes covered by BITs and ICSID jurisdiction. Providers of services and holders of intellectual property rights will have to examine very carefully the alternative dispute settlement fora for enforcing their private rights and the corresponding government obligations. In the field of international telecommunications, for example, the recent WTO panel report on Mexico-Measures Affecting Telecommunications Services illustrates that the market access commitments, national treatment commitments and additional commitments (e.g. for competition rules) accepted by WTO Members for the liberalization of international telecommunications services are justiciable and enforceable through the WTO dispute settlement system. $^{38}$ By contrast, the alternative arbitration procedures of the International Telecommunications Union (ITU) have never been applied so far: the "traditional ITU dispute settlement procedures, with their application restricted to ITU Member States and limited to matters related to the interpretation and application of the ITU instruments, are not of any use to the ever growing number of private sector telecommunications services and equipment providers independent of governments or quasi-governmental organizations. ${ }^{39}$

(10) The numerous WTO guarantees of private access to domestic courts (e.g. in Article X GATT, Article 13 Anti-Dumping Agreement, Article 23 Agreement on Subsidies, Articles 32,41-50 TRIPS Agreement) have given rise to an increasing number of parallel or successive dispute settlement proceedings in domestic courts and before WTO dispute settlement bodies, e.g. on the review of anti-dumping determinations, countervailing duty determinations, government procurement practices and regulation of intellectual property rights. As goods and services are produced and consumed by individuals, WTO dispute settlement panels have emphasized that "one of the primary objects of the GATT/WTO ... is to produce certain market conditions which would allow ... individual activity to flourish" by protecting the international division of labor against discriminatory trade restrictions and other distortions. ${ }^{40}$ Yet, the same dispute settlement panel also emphasized that "(n)either the GATT nor the WTO has so far been interpreted by GATT/WTO institutions as a legal order producing direct effect", i.e. creating rights and obligations not only for WTO members but also direct individual rights for traders, producers and consumers. ${ }^{41}$ WTO obligations have been recognized

${ }^{37}$ Cf. G.Verhoosel, The Use of Investor-State Arbitration under Bilateral Investment Treaties to Seek Relief for Breaches of WTO Law, in: JIEL 6 (2003), 493-506. See also the UNCTAD series on issues in international investment agreements, e.g.: Trends in International Investment Agreements: An Overview, UN 1999; Dispute Settlement: Investor-State, UN 2003. See further G.Sacerdoti, Bilateral Treaties and Multilateral Instruments on Investment Protection, in: Recueil des Cours 1997, 251-460.

${ }^{38} \mathrm{Cf}$. WT/DS204/R of 2 April 2004, adopted in June 2004.

39 A.A.E.Noll, The Various Approaches to Dispute Settlement Concerning International Telecommunications, in: Arbitration in Air, Space and Telecommunications Law, Permanent Court of Arbitration (editor), 2002, 160-192, at 171. Noll distinguishes between "purely telecommunication sector-specific disputes" and those that are more concerned with trade in telecommunications services regulated by the GATS, and suggests to coordinate ITU dispute settlement procedures (limited to ITU instruments and ITU member states) and WTO dispute settlement procedures in the agreement concluded among the WTO and ITU pursuant to Article V of the WTO Agreement and Section 7 of the GATS Annex on Telecommunications.

${ }^{40}$ See: United States - Sections 301-310 of the Trade Act of 1974, panel report adopted on 27 January 2000, WT/DS152/R, paras. 7.73 et seq.

${ }^{41}$ See the panel report in note 25 , at para.7.72. The Panel makes the following important reservation: "The fact that WTO institutions have not to date construed any obligations as producing direct effect does not 
as an "integral part of the Community legal order" inside the EC and have been incorporated into the domestic laws of many WTO members. But the EC Court of Justice - like the domestic courts of some other WTO members - has concluded from the intergovernmental structures and reciprocity principles of WTO law that the "purpose of the WTO agreements is to govern relations between States or regional organizations for economic integration and not to protect individuals" who, as a consequence, "cannot rely on them before the courts and ... any infringement of them will not give rise to non-contractual liability on the part of the Community."42 As a result of the widespread disregard of WTO rules by domestic courts, parallel or successive dispute settlement proceedings in domestic courts and before WTO dispute settlement panels often lead to conflicting or otherwise inconsistent decisions entailing legal insecurity, high transaction costs, and challenges to the legitimacy of intergovernmental WTO rules and secretive WTO dispute settlement procedures.

In contrast to the vast literature and judicial practice concerning "forum shopping" and ADR in private international litigation, the respective merits and venue choices of concurrent jurisdictions for international disputes over governmental restrictions (e.g. taxes, non-tariff trade barriers) and governmental trade distortions (e.g. subsidies, trade discrimination), and the related problems of ADR, have so far been little studied in public international trade law. Many of the several hundred bilateral, regional and worldwide trade and economic agreements provide for political and legal dispute settlement procedures with, in part, overlapping jurisdictions and alternative dispute resolution mechanisms. Choosing the right dispute prevention and dispute settlement forum, and avoiding less advantageous dispute settlement fora, are therefore also important tasks in international trade policy and public trade law (below chapter IV). Chapter V discusses examples and case-studies of ADR in public international trade and investment law. Views on the optimal negotiation forum or judicial forum may differ depending on whether one focuses on the interests of the complaining government or defendant government, or on the private economic interests affected by the dispute. Chapter VI distinguishes five different categories of international trade disputes, depending on the conflicts of interests underlying the dispute concerned, and recommends different conflict prevention and dispute settlement procedures for each category of international dispute. Chapter VII concludes with a few policy recommendations for additional international rules on the prevention of international trade disputes and the coordination of concurrent jurisdictions for judicial dispute settlement proceedings.

\section{Alternative Dispute Settlement Methods in International Economic Law: An Overview}

Disputes are characterized by (1) specific disagreements concerning matters of fact, law or policy between (2) two or more parties so that (3) a claim or assertion by one party is met with refusal, counter-claim or denial by another. In order to distinguish disputes from divergent claims, "disputes" may be defined by the additional criterion (4) that one or more parties

necessarily preclude that in the legal system of any given Member, following internal constitutional principles, some obligations will be found to give rights to individuals. Our statement of fact does not prejudge any decisions by national courts on this issue."

${ }^{42}$ According to the same judgment, "it is only where the Community intended to implement a particular obligation assumed in the context of the WTO, or where the Community measure refers expressly to the precise provisions in the WTO agreements, that it is for the Community judicature to review the legality of the Community measure in question in the light of the WTO rules", cf. EC Court of Justice, Case T-210/00 (Etablissement Biret SA v. EU Council), in: Common Market Law Reports 31 (2002), 787808 (paras. 71-73). 
require the dispute to be settled by recourse to additional dispute settlement procedures. ${ }^{43}$ The close interrelationships between intergovernmental and private disputes are reflected in many WTO dispute settlement reports, for instance when WTO panels emphasized that disputes among trading countries, and violations of WTO rules, usually result from discriminatory treatment by WTO member governments of producers, traders or other individual participants in the market place:

"Trade is conducted most often and increasingly by private operators. It is through improved conditions for these private operators that Members benefit from the WTO disciplines. The denial of benefits to a Member which flows from a breach is often indirect and results from the impact of the breach on the market place and the activities of individuals within it." 44

This chapter begins with a brief overview of the ten traditional dispute settlement methods in public international law which are also available in WTO law (section 1). It then explains why, from a citizen perspective, these intergovernmental methods are often neither legally effective nor economically efficient methods for preventing or settling disputes among private producers, investors, traders, consumers and foreign governments (section 2). As most intergovernmental WTO disputes are triggered by private complaints (e.g. pursuant to the complaint procedures provided for in Section 301 of the US Trade Act, or the corresponding procedures in the EC's Trade Barriers Regulation), and many WTO dispute settlement proceedings are carried out through "private-public partnerships" among the private complainants and their government representatives in the $\mathrm{WTO}^{45}$, examining one's "best alternative to a negotiated agreement" (= BATNA) ${ }^{46}$, and the most appropriate ADR methods, must be the starting point for successful litigation or dispute prevention strategies (section 3 ).

\section{THE TEN TRADITIONAL DISPUTE SETTLEMENT METHODS IN PUBLIC INTERNATIONAL LAW AND WTO LAW}

The numerous international dispute settlement treaties concluded since the 1899 and 1907 Hague Conventions for the Pacific Settlement of Disputes ${ }^{47}$ tend to distinguish ten different international dispute settlement methods: (1) bilateral and/or multilateral negotiations; (2) good offices; (3) mediation; (4) inquiries; (5) conciliation; (6) ad hoc or institutionalized arbitration; (7) judicial settlement by permanent courts; (8) "resort to regional agencies or arrangements", or (9) to "other peaceful means of their own choice" (Article 33 UN Charter); and (10) dispute settlement by the UN Security Council (e.g. pursuant to Articles 34-38 UN Charter) or by other UN organs or other international organizations. ${ }^{48}$ Many international treaties, including the UN Charter and the WTO Agreement, view these political and legal procedures as complementary options and define the conditions for their use. The international law principles of "free choice of means", and of "international consent" as a precondition for international adjudication, entail that - apart from the general international law obligation to

43 See F.Berman, Legal Theories of International Dispute Prevention and Dispute Settlement, in: E.U.Petersmann/M.Pollack (note 24), 451-464.

${ }^{44}$ WTO Panel report on United States -Sections 301-310 of the Trade Act of 1974, WT/DS152/R, para. 7.77 .

${ }^{45}$ Cf. Greg Shaffer (note 21).

46 The importance of examining one's BATNA is explained in: R.Fisher/W.Ury (note 6).

${ }^{47}$ Cf. K.Oellers-Frahm/N.Wühler, Dispute Settlement in Public International Law. Texts and Materials, Springer Publishers Berlin 1984; Handbook on the Peaceful Settlement of Disputes between States, UN New York 1992.

${ }^{48}$ For explanations of the differences among these procedures see e.g.: J.G.Merrills, International Dispute Settlement, 3rd ed. Manchester University Press 1998. 
"settle their international disputes by peaceful means" (Article 2:2 UN Charter) - no one method of dispute settlement is legally privileged over any other unless countries agree otherwise (e.g. in Article 23 of the DSU, Article 292 EC Treaty).

Also after the creation of the Permanent Court of Arbitration in 1899 and of the Permanent Court of International Justice (PCIJ) in 1920, negotiations have remained the principal means for the prevention or settlement of disputes among states. Bilateral negotiations and third-party-assisted ,political methods“ of dispute settlement can offer important advantages such as: greater flexibility, privacy and control by the parties over the outcome; comparatively less costs; the taking into account of political as well as legal considerations; and avoidance of "winner-loser" situations. Yet, notwithstanding the increasing number of international treaty provisions on good offices, mediation, inquiry and conciliation, these third-party-assisted diplomatic means of international dispute settlement (e.g. commissions of inquiry, conciliation commissions) are less frequently invoked in international economic relations than alternative legal methods of adjudication, arbitration or quasi-judicial dispute settlement mechanisms. ${ }^{49}$ "Diplomatic methods" of dispute settlement (such as „,voluntary export restraints“) are often criticized as being "power-oriented", as not sufficiently focusing on the merits of each party's case, as weakening the previously agreed rules and undermining legal security.

Legal dispute settlement methods enable rule-oriented, legally binding decisions by independent judges based on "due process of law" and substantive rules that were previously agreed as reflecting the long-term interests of the parties to the dispute. According to Article 92 of the UN Charter, the ICJ was to become the "principal judicial organ" for the settlement of disputes among UN member states. Yet, less than a third of the $191 \mathrm{UN}$ member states have so far accepted the compulsory jurisdiction of the ICJ (Article 36 of the ICJ Statute), and this often subject to far-reaching reservations. The about hundred contentious disputes submitted to the ICJ since 1946 concerned mainly disputes over territorial delimitation and bilateral treaties. Only a few economic and investment disputes were submitted to the ICJ; international trade disputes were hardly ever decided by the ICJ nor by its predecessor, the PCIJ. ${ }^{50}$ Due to the lack of standing of individuals, of non-governmental as well as of intergovernmental organizations before the ICJ, and the long duration and numerous shortcomings of ICJ procedures, the prospects of transforming the ICJ into a true world court with mandatory universal jurisdiction - e.g. for resolving also jurisdictional disputes resulting from competing jurisdictions for the resolution of specific international disputes (similar to the task of the EC Court of Justice in relation to disputes arising under the Brussels and Lugano Conventions on the jurisdiction of national courts for transboundary disputes) - are slim: most states appear unwilling to empower the ICJ to decide on international disputes which the same states, for good reasons (such as lack of ICJ expertise in international economic law), have so far excluded from the jurisdiction of the ICJ. ${ }^{51}$ Just as many member states of the European Convention on Human Rights (ECHR) have submitted reservations limiting the jurisdiction of the UN Human Rights Committee for complaints under the Optional Protocol to the UN Covenant on Civil and Political Human Rights if the same complaint is pending before the human rights bodies established under the ECHR, most members of regional economic integration agreements (such as the EC, the European Economic Area, NAFTA) appear unwilling to limit the

${ }^{49} \mathrm{Cf}$. Merills (above note 48) and C.Chinkin, Alternative Dispute Resolution under International Law, in: M.Evans (ed.), Remedies in International Law, 1998, at 123, 124.

${ }^{50} \mathrm{Cf}$. G.Jaenicke, International Trade Conflicts before the PCIJ and the ICJ, in: E.U.Petersmann/G.Jaenicke (eds.), Adjudication of International Trade Disputes in International and National Economic Law, 1992, at 43, 44; P.S.Rao, Course on Dispute Settlement: International Court of Justice, UN 2003.

${ }^{51}$ Cf. Shany (note 15), 273-277. 
exclusive jurisdiction of regional and worldwide economic courts (such as the ECJ, the EFTA Court, the WTO dispute settlement bodies) in favor of an ICJ jurisdiction to resolve conflicts of jurisdictions, and related problems of forum choice, parallel or successive judicial proceedings among specialized judicial bodies in international economic law.

The legal methods for the settlement of international economic disputes are characterized by an increasing proliferation of worldwide and regional courts and quasijudicial dispute settlement procedures (e.g. in the WTO), with increasing reliance on alternative dispute settlement methods, for example by means of mixed international arbitration between a state and a private party. All the major alternative dispute settlement methods of public international law - e.g. bilateral and multilateral consultations, good offices, conciliation, mediation, panel and appellate review procedures, arbitration, national and international adjudication - are available also in WTO law for the prevention and settlement of international trade disputes. In contrast to the restrictive ICJ practice under Articles 62 and 63 of its Statute with regard to intervention by third parties ${ }^{52}$, GATT and WTO dispute settlement proceedings are characterized by frequent participation of third parties in consultations, panel proceedings and appellate review as a means of conflict avoidance and prevention of separate, additional disputes. ${ }^{53}$ The rights (e.g. under Article 4.11 of the DSU) of third WTO Members having a "substantial trade interest" to request to join consultations under Article XXII of GATT 1994 (or under the analogous provisions of other covered agreements) are frequently exercised, just as multiple complaints by more than one WTO Member pursuant to Article 9 of the DSU are frequent in WTO dispute settlement practice. In the 1996/1997 panel proceeding against the EC's import restrictions for bananas, for instance, there were 5 complainants, 8 WTO members intervening in support of these "multiple complainants", and 12 WTO member countries intervening in support of the EC as defendant (the $15 \mathrm{EC}$ member states participated in the dispute as part of the EC delegation without a formal status as "co-defendants" or "third parties").

\section{WHY INTERGOVERNMENTAL DISPUTE SETTLEMENT METHODS ARE OFTEN SUB-OPTIMAL IN INTERNATIONAL ECONOMIC LAW}

Most international trade and economic transactions take place between private producers, investors, traders and consumers. International trade disputes are about how to reconcile the respective interests of producers, investors, traders and consumers with the public interests of the exporting and importing countries involved. Optimal dispute prevention and dispute settlement methods should aim at regulating these conflicts of interests in a nondiscriminatory and welfare-enhancing manner (e.g. by limiting welfare-reducing border discrimination) and should legally protect and empower all the actors involved to defend their legitimate rights and resolve disputes in a decentralized manner. Dispute prevention and dispute settlement are characterized by ever more precise national, international and transnational guarantees of equal freedoms and rule of law limiting abuses of power in

${ }^{52} \mathrm{On}$ the restrictive ICJ practice with regard to "discretionary intervention" pursuant to Article 62 of the ICJ Statute (for which the intervenor has to specify an "interest of a legal nature" as well as "any basis of jurisdiction which is claimed to exist as between the State applying to intervene and the parties to the case", cf. Article 81 of the Rules of the Court), and "intervention as of right" pursuant to Article 63 of the ICJ Statute, see S.Rosenne, Intervention in the International Court of Justice, 1993; C.Chinkin, Third Parties in International Law, 1993.

${ }^{53}$ Cf. F. Weiss, Third Parties in GATT/WTO Dispute Settlement Proceedings, in: Liber Amicorum Paul de Waart, 1998, 458-472; M.Footer, Some Aspects of Third Party Intervention in GATT/WTO Dispute Settlement Proceedings, in: E.U.Petersmann (ed.), International Trade Law and the GATT/WTO Dispute Settlement System, 1997, 211-244. 
national, international and transnational relations for the benefit of legally protected freedom, non-discriminatory conditions of competition, and respect for human rights. As rules do not enforce themselves, rule of law depends on effective legal and judicial remedies, as reflected in the human right of access to justice. The "struggle for rights", and the judicial protection and balancing of rights, are often necessary elements for the clarification, progressive development and effectiveness of rules.

From the point of view of private economic operators, following the traditional international law rules on prior exhaustion of local remedies and subsequent espousal of private claims against foreign governments by the home state in order to initiate diplomatic protection and intergovernmental court proceedings, often means that international legal and judicial remedies may only become available many years after the dispute arose. For example, the judgment by the ICJ in the ELSI dispute between the United States and Italy over the treatment of US investors in Palermo was rendered in 1989 more than 25 years after the investment dispute arose in Italy. ${ }^{54}$ Moreover, the ELSI judgment has been subject to severe criticism in the literature. ${ }^{55}$ The two and a half years between the institution of the ICJ proceedings on 6 February 1987 and the judgment of 20 July 1989, and the 12 public sittings held by the ICJ so as to listen to the numerous agents, counsels and advocates representing the two states, indicate that ICJ proceedings tend to last much longer and to cost much more than ICSID arbitration or WTO panel proceedings. The lack of private access to the ICJ, the virtual absence of damage awards rendered by the ICJ, and the rare use of expert and witness testimony before the ICJ, are among the many reasons why private access to the EC Courts, the EFTA Court, NAFTA or ICSID arbitration, without prior exhaustion of local remedies (cf. Article 26 of the ICSID Convention), are often perceived by business as more appropriate for the settlement of international trade and investment disputes and claims to reparation of injury. ${ }^{56}$

In private national and international commercial law, ADR is increasingly recognized as an important alternative to adversarial arbitration or court litigation, whose higher costs, longer duration and sometimes lesser predictability (e.g. in case of juries and punitive damages) are viewed as less advantageous than ADR. ${ }^{57}$ The various ADR methods (such as mediation, neutral expert appraisal, mini-trial) differ from judicial procedures by the agreed intervention of a third party which helps the parties to settle their dispute in a more flexible, expeditious, confidential and less costly manner, yet without rendering a legally binding decision. The voluntary, non-binding and informal character of ADR proceedings ensures control by the parties over their dispute and focuses on elaborating "win-win" solutions that save time and costs and strengthen personal and business relationships among the parties to the dispute. ADR is considered particularly beneficial for international commercial relations and disputes among parties from different legal systems and cultures, especially if both parties are interested in continued long-term cooperation, their dispute is not about a principal point of

${ }^{54}$ ICJ Reports 1989, 15-121; ILM 1989, 1111-1164.

${ }^{55}$ See the critical comments (e.g. on the unusual ICJ finding that an illegal requisition order under Italian law should not also constitute a breach of the FCN Treaty obligations) by F.A.Mann, Foreign Investment in the ICJ: The ELSI Case, in: AJIL 1992, 92-102, who also criticizes "the Court's lack of appreciation of the very specific facts of the case, the narrow reasoning and the almost complete adherence to conceptualism as opposed to equity" (p.92) in the ICJ's Barcelona Traction judgment.

56 See e.g. S.D. Murphy, The ELSI Case: An Investment Dispute at the ICJ, in: Yale Journal of International Law, 1992, 391-452, at 439, 442.

${ }^{57}$ See e.g. P.W.Eysten, Alternative Dispute Resolution in Commercial Disputes, and A.J.Eijsbouts, ADR and Arbitration: Advantages and Disadvantages in Commercial Disputes, in: W.P.Heere (ed.), International Law and the Hague's 750th Anniversary, 1999, 219-228; A.Redfern/M.Hunter (eds), Law and Practice of International Commercial Arbitration, $3^{\text {rd }}$ ed. 1999, chapter 1. 
law, and there is no discrepancy regarding their respective bargaining power and positions. Once a mutually acceptable settlement agreement is signed, the result of ADR may become legally binding, yet ideally without leaving a "loser" and without being limited to the traditional court remedies (such as specific performance, rescission of the contract, or damages).

\section{PUBLIC-PRIVATE PARTNERSHIPS IN WTO LITIGATION: NEED FOR EXAMINING ONE'S “BATNA"}

Only WTO Members may be parties to WTO dispute settlement proceedings. Yet, most WTO complaints are triggered by private domestic complaints, for instance pursuant to Section 301 of the US Trade Act and the corresponding Trade Barriers Regulation of the EC ${ }^{58}$ This private origin of most WTO disputes is reflected in the designation of many WTO disputes by the names of the companies involved ("Kodak/Fuji", "Pernod-Ricard/Bacardi-Martini"). WTO litigation is typically characterized by "the formation of public-private partnerships to pursue varying, but complementary goals." ${ }^{59}$ This blurring of public and private interests in international trade law renders it even more important to clarify: Who's interests should intergovernmental consultations, mediation, conciliation, panel, Appellate Body or arbitration proceedings in the WTO serve?

The answer by public international lawyers that governments are supposed to serve the "public interest", cannot explain the political reality that governments often violate their WTO obligations, or resort to intergovernmental WTO dispute settlement proceedings, in order to protect powerful group interests in exchange for their political support. For example, several WTO complaints initiated by the US (e.g. against EC import restrictions on bananas) were linked to election campaign promises in exchange for financial campaign contributions in US federal elections. In the case of WTO complaints by less-developed WTO Members with less administrative resources and less legal expertise, the private petitioners (e.g. an export industry) sometimes prepare the complaint, cover the costs for outside legal counsel, and participate in the governmental "legal team" of the WTO Member presenting the complaint in the intergovernmental dispute settlement proceeding. Also NAFTA rules (e.g. in Chapter 11 on the protection of foreign investors and investments) and NAFTA dispute settlement procedures are often characterized by a one-sided focus on business interests (e.g. in NAFTA Article 1110 on prompt compensation of the market value of "expropriated investments") which, compared to European integration law, appear less constrained by "public interest clauses". Dispute prevention and an agreed dispute resolution may thus require "multi-level" negotiations not only among the governments, but also among the private parties concerned, and among the private parties and their respective governments.

Negotiation theories emphasize the importance of bearing in mind one's "BATNA" (= Best Alternative To a Negotiated Agreement) so as to make sure that the negotiation produces something better than the result that may be obtained unilaterally without negotiating. If the primary interest lies in judicial clarification of the contested meaning of an existing legal obligation so as to avoid future disputes, unilateral recourse to compulsory jurisdiction (e.g. of a WTO panel, the EC Court of Justice, or a national court) may be the preferred "BATNA." If the "BATNA" of the weaker party does not include the possibility of unilaterally submitting the dispute to previously agreed compulsory jurisdiction (e.g. in disputes involving the majority of UN Members which have not recognized the compulsory jurisdiction of the ICJ), the more powerful party may be tempted to use its bargaining power and oppose the request by a weaker

\footnotetext{
${ }^{58}$ Cf. Molyneux (note 13).

${ }^{59}$ Shaffer (note 21), at 4 .
} 
party of submitting the dispute to third-party adjudication. Game theory ${ }^{60}$ teaches that the principle of predictable "tit-for-tat" offers the best strategy for promoting reciprocal cooperation among egoists in a decentralized context where, as in many fields of international law, there is no central authority that can enforce agreed international rules.

For example, the fact that - prior to the 2003 complaint by Antigua and Barbuda against US restrictions on the cross-border supply of gambling and betting services - leastdeveloped countries (LLDCs) have not been involved as complainants or defendants in WTO panel proceedings appears to be due not to the lack of disputes, but rather to the preference of settling disputes involving LLDCs without recourse to costly WTO dispute settlement proceedings, for example in view of the fact that most of their exports take place under voluntary tariff preferences granted under the 1979 GATT Decision on Differential and More Favorable Treatment, Reciprocity and Fuller Participation of Developing Countries ("Enabling Clause") ${ }^{61}$ and pursuant to special WTO "waivers" (e.g. for EC tariff preferences under the Cotonou Agreement with 77 African, Caribbean and Pacific countries). LLDCs may have neither the legal, economic and professional resources for costly and time-intensive WTO litigation nor adequate private support from their export industries for preparing a WTO complaint. The prospective trade remedies offered by WTO law (cf. Articles 3:7,19 DSU) may also be less attractive for LLDCs than alternative financial reparation of injury that may be available in alternative dispute settlement proceedings. However, given the asymmetries in bargaining power between LLDCs and their developed trading partners, recourse to the special legal services offered by the International Advisory Center for WTO Law ${ }^{62}$ and, to a limited extent, also by the WTO (cf. Article 27:2 of the DSU) may be important for clarifying the relevant rights, obligations and most advantageous dispute settlement strategies. Yet, joint multilateral consultations, renegotiation of WTO rules (e.g. in the Doha Development Round), or requests for ad hoc "waivers" may be more favorable dispute prevention strategies for LLDCs than WTO litigation. The fact that the Advisory Center on WTO Law has, in a number of cases, advised less-developed countries against initiating WTO panel proceedings illustrates that dispute avoidance remains a primary objective of the WTO dispute settlement system.

\section{Alternative Dispute Resolution (ADR) in the WTO: Some Case-Studies}

Prior to the entry into force of the WTO Agreement in 1995, international trade law, investment law and intellectual property law had evolved in separate institutional frameworks (e.g. GATT, WIPO, World Bank Group) that provided for separate dispute settlement procedures (e.g. GATT Article XXIII, ICJ, ICSID). WTO law, by contrast, covers not only international trade in goods and services but also trade-related intellectual property rights and trade-related investments (e.g. under the WTO Agreements on Trade-Related Investment Measures, the GATS and the Agreement on Government Procurement). The DSU offers Members the choice among bilateral and multilateral consultations (Article 4), good offices, conciliation and mediation (Article 5), dispute settlement panels (Articles 6-16), appellate

${ }^{60}$ Cf. R.Axelrod, The Evolution of Cooperation, 1984, notably at 27, 180.

${ }^{61}$ See, however, India's successful WTO panel proceeding challenging the legal consistency, with GATT 1994 and the Enabling Clause, of certain conditions and discriminatory trade preferences under the GSP scheme of the EC, cf. WT/DS264/R of 1 December 2003. The panel findings were upheld, yet with modified reasoning, by the Appellate Body (WT/DS246/AB/R) in April 2004.

${ }^{62}$ The Advisory Center on WTO Law was created by an international agreement signed by 29 countries at the WTO Ministerial Meeting at Seattle on 1 December 1999 which entered into force in July 2001. Its first annual report on its activities from July 2001 to June 2002 is published on its website at www.acwl.ch. The Center has currently 36 member countries. In addition to its 25 less-developed member countries, the 40 LLDCs may use the services of the Center without being members. 
review (Article 17) and arbitration (Articles 21,22,25). Article 23 of the DSU requires WTO Members to settle their disputes about the interpretation and (non-) application of WTO rules pursuant to WTO dispute settlement procedures. This obligation to have recourse to the "compulsory WTO jurisdiction" does, however, not obviate the need to examine ADR options. $^{63}$

\section{THE 'HAVANA CLUB' DISPUTE IN THE WTO: PRIVATE INTELLECTUAL PROPERTY DISPUTES SHOULD NOT UNNECESSARILY BE CONVERTED INTO INTERNATIONAL POLITICAL DISPUTES}

The 'Havana Club' dispute between the EC and the US in the WTO arose from a private commercial dispute between Pernod Ricard, a France-based multinational distiller and distributor, and Bacardi-Martini, a U.S.-based multinational distiller and distributor, over their rights in the trade mark 'Havana Club'. ${ }^{64}$ Each company was fully cognizant that its respective claims to the trade mark remained controversial in view of the nationalization of the trade mark rights by the Cuban government in the early 1960s. After having litigated their dispute in US courts, the companies succeeded in transforming their private dispute into an intergovernmental challenge of world trade rules with the risk of transatlantic trade sanctions. Submission of their private dispute to private third party arbitration or mediation (e.g. in WIPO's arbitration center) might have avoided the international political dispute and might have clarified the private rights more quickly and more effectively.

The intergovernmental EC complaint was directed against United States - Section 211 Omnibus Appropriations Act of 1998. The prime issue before the WTO panel and Appellate Body (AB) was whether Section 211 of the Omnibus Appropriations Act of 1998, notably its ban of the protection and recognition of trademarks and trade names in connection with Cuban business relations, was compatible with the TRIPS Agreement. ${ }^{65}$ The AB, applying the rules of the TRIPS Agreement and of the Paris Convention on Industrial Property, confirmed the panel's view that Article 6quinquies of the Paris Convention requires accepting trademarks for registration in the same form, without eliminating Member discretion to apply rules concerning other rights in marks. Articles 15 and 16 of the TRIPS Agreement were found not to prevent individual WTO Members from making their own determination regarding the ownership of marks within the boundaries established by the Paris Convention. Article 42 of the TRIPS Agreement regarding procedural rights was held not to obligate a Member to permit adjudication of each substantive claim regarding trade mark rights a party might assert, if that party is fairly determined $a b$ initio not to be the holder of an interest in the subject mark. In sum, the AB confirmed the right of the United States to refuse registration and enforcement of trademarks it determines to have been confiscated in violation of international law.

${ }^{63}$ ADR is usually defined as "an umbrella term that refers generally to alternatives to the court adjudication of disputes such as negotiation, mediation, arbitration, mini-trial and summary jury trial" , cf. J.M.Nolan-Haley, Alternative Dispute Resolution, 2nd ed. 2001, at 1-2. In this article, the term ADR is used in a broader sense referring to all alternative, political and legal, national and international dispute resolution options. For a survey of ADR procedures and practices in international law, see also the contribution by K.Venkata Raman, Course on Dispute Settlement: Good Offices, Mediation and Conciliation of International Trade and Investment Disputes, UNCTAD 2003.

${ }^{64}$ For a thorough case-study see: F.M.Abbott/T.Cottier, Dispute Prevention and Dispute Settlement in the Field of Intellectual Property Rights and Electronic Commerce: US-Section 211 Omnibus Appropriations Act 1998 ('Havana Club'), in: Petersmann/Pollack (note 24), 429-447.

${ }^{65}$ WTO Appellate Body, United States - Section 211 Omnibus Appropriations Act of 1998, WT/DS176/AB/R, 2 January 2002 (“U.S. - Havana Club”). 
Contrary to the WTO panel findings that certain formal legal differences in the treatment of U.S. nationals and foreign nationals in the relevant US legislation did not amount to a violation of the national treatment obligations of the TRIPS Agreement (Article 3), the AB found that even though the likelihood of effective discrimination might be small - the possibility of additional procedural hurdles for non-U.S. nationals was inherently less favourable and contrary to Article $3{ }^{66}$ Similarly, the $\mathrm{AB}$ found that formally different treatment of nationals of Cuba and other foreign countries ("non-Cuban foreign nationals") established a prima facie inconsistency with the obligation of most-favored-nation treatment (Article 4 of the TRIPS Agreement). Yet, since the EC's main claim that the U.S. lacked the power to deny ownership of the subject mark for the United States was not upheld by the AB, the risk of transatlantic trade sanctions in order to enforce these very strict interpretations of Articles 3 and 4 - with adverse effects on EC and US traders and consumers not involved in this dispute - was a dangerous result of transforming "a fairly ordinary commercial trademark dispute between two well-financed private enterprises into a matter of high politics." 67

\section{WTO DISPUTES OVER TRADE-RELATED INVESTMENT MEASURES (TRIMS) MAY BE SETTLED MORE EFFECTIVELY OUTSIDE THE WTO}

The so far four WTO disputes under the WTO Agreement on TRIMS, and the increasing number of WTO disputes over the rights of private services suppliers, foreign investors and intellectual property holders under the GATS and TRIPS Agreements, often involve disputes not only over rights and obligations of WTO Members but also over private rights and claims of injury caused by illegal government measures. Since about one third of world trade is intra-firm trade among subsidiaries of multinational corporations, illegal trade restrictions may at the same time result in illegal treatment of foreign investors. Most BITs provide that the legal obligations of host states to grant most-favored-nation treatment or national treatment to foreign investors must be determined in the light of relevant international law rules, which may include the WTO obligations of the host state concerned. Even if the intergovernmental dispute is submitted to the WTO, the private economic operators may challenge the foreign government measure through investor-state arbitration pursuant to the dispute settlement procedures of the BIT, Chapter 11 of NAFTA, in the EC Court of Justice (e.g. by Ecuadorian and US banana exporting companies challenging the EC import restrictions on bananas), or in other domestic courts. Under general international law and WTO law, private recourse to domestic or regional courts and "mixed" investor-state arbitration do not preclude the host state of an investor from initiating WTO dispute settlement proceedings. $^{68}$

Both inside the WTO as well as in fora outside the WTO, such trade-related investment disputes may raise new legal and procedural questions. For instance:

- To what extent can WTO dispute settlement bodies apply investment rules and intellectual property rules agreed upon by both parties to the dispute outside the WTO framework (e.g. the WIPO Copyright Treaty and WIPO Performances and Phonograms Treaty concluded in December 1996 and not yet formally incorporated into the TRIPS Agreement)?

- $\quad$ Given the traditional limitation of the applicable law in WTO panel and appellate review procedures to WTO law and to a few principles of general international law:

\footnotetext{
${ }^{66}$ Appellate Body Report, para.265.

${ }^{67}$ Abbott/Cottier (note 64), at 439.

${ }^{68}$ Cf. e.g. Verhoosel (note 37 ), at 495.
} 
Can the complainant invoke the general international law rules on state responsibility in an investment dispute before a WTO panel and request reparation of injury?

- $\quad$ Are there certain categories of disputes which, in the interest of both the complainant and the defending country, could be more effectively settled by "arbitration within the WTO as an alternative means of dispute settlement", as provided for in Article 25 of the DSU?

- $\quad$ Since WTO law does not specify the arbitration procedures: Could the parties to "arbitration within the WTO" use the "Permanent Court of Arbitration (PCA) Optional Rules for Arbitrating Disputes between Two States“699 as a basis for mutually agreed arbitration in the WTO?

- $\quad$ As, pursuant to Article 33 of these PCA arbitration rules, the "arbitral tribunal shall apply the law chosen by the parties, or in the absence of an agreement, shall decide such disputes in accordance with international law": Could the parties to the dispute request the arbitral tribunal to apply not only WTO law but also general international law and e.g. a bilateral investment treaty (BIT) accepted by both parties?

- If the defending country does not agree to such arbitration "within the WTO" (Article 25 DSU): Could the complaining country unilaterally invoke the "compromissory clause" contained in many BITs providing for ICJ or ICSID jurisdiction and challenge discriminatory regulations by the host state not only under the non-discrimination obligations of WTO law before a WTO panel, but also under the non-discrimination requirements of the BIT before the ICJ or an ICSID arbitral tribunal?

- $\quad$ Can other substantive and procedural international treaty obligations, for instance under multilateral conventions on intellectual property conventions administered by WIPO which often provide for jurisdiction of the ICJ, be invoked in parallel to WTO dispute settlement proceedings?

- Which categories of investment or intellectual property disputes could, in the interest of both the private investor and the host state, be more efficiently handled by less politicized "mixed arbitration procedures" between the investor and the host state in the framework of ICSID or WIPO arbitration procedures? Under what conditions can violations of WTO obligations entail that treatment of adversely affected investors is not "in accordance with international law" as required by BITs and the NAFTA Agreement (e.g. Article 1105) ${ }^{70}$ Does, in case of violations of WTO rules, the lack of WTO guarantees for reparation of damages influence the interpretation of the relevant rules on state responsibility under BITs?

- What are the comparative advantages, disadvantages and potential legal problems of trade and investment disputes in the WTO, ICJ, PCA, ICSID, WIPO, before domestic courts or private arbitral tribunals (e.g. applying the arbitration procedures of the UN Commission on International Trade Law or of the International Chamber of Commerce)?

Given the longstanding limitation of legal remedies under GATT and WTO law, as reflected in Article 19 of the DSU, private investors and holders of intellectual property rights may prefer to submit disputes over alleged violations of such private rights to dispute settlement fora other than the WTO in order to secure legal rulings not only on the illegality and termination of the contested government measures, but also on reparation of injury. Most BITs protect foreign investments in a broadly defined manner, including investor rights and

${ }^{69}$ Cf. Permanent Court of Arbitration, Basic Documents, 1998, pp. 41-68.

70 On this question see the NAFTA jurisprudence, and the very restrictive "Notes of interpretation" adopted by the NAFTA Free Trade Commission in July 2001, discussed by Verhoosel (note 37). 
intellectual property rights covered by GATS and by the TRIPS Agreement. While earlier BITs often provided only for recourse to the ICJ or ad hoc arbitration of State-to-State disputes, modern BITs also include provisions for investor-State arbitration pursuant to the procedures of the ICSID, the UN Commission on International Trade Law (UNCITRAL), the International Chamber of Commerce (ICC) or other arbitration institutions. Most modern BITs offer a choice between different arbitral regimes, and no longer insist on prior exhaustion of local remedies. Under ICSID and some BITs, resort to investor-State arbitration may preclude recourse to State-to-State dispute settlement for the same dispute. While investor-State arbitration may provide for the award of monetary damages, arbitral tribunals may lack the power to order a host State to revoke or modify an illegal government measure. ${ }^{71}$

The GATT and WTO disputes over trade-related investment measures illustrate that, for instance, discriminatory local purchase requirements, performance or licensing requirements imposed on foreign investors in violation of the national treatment requirements of GATT/WTO law may also violate the national treatment requirements in BITS and give rise to investor-State arbitration on claims of reparation of injury. The WTO Panel Report of 2 July 1998 on Indonesia - Certain Measures Affecting the Automobile Industry ${ }^{72}$, which was adopted by the WTO on 23 July 1998, illustrates some of the advantages and potential disadvantages of investment disputes in the WTO. For instance:

a) The short time of less than one year between the composition of the Panel on 29 July 1997 and the adoption of the lengthy panel report (398 pages) by the Dispute Settlement Body (DSB) on 23 July 1998 shows the relative speed of WTO dispute settlement proceedings.

b) The WTO panel dealt with three initially different complaints by Japan, the European Communities and the United States. Following Article 9 of the DSU, the DSB established a single panel to examine these three complaints. The Panel organized its examination and presented its findings to the DSB "in such a manner that the rights which the parties to the dispute would have enjoyed had separate panels examined the complaints (were) in no way impaired" (as requested by Article 9:2 of the DSU). These "multiple complainants procedures" are relatively frequent in WTO dispute settlement practice and enable important synergies for all parties involved.

c) India and Korea intervened as third parties in the WTO panel proceeding in support of Indonesia. This frequent practice of third party intervention in WTO dispute settlement proceedings offers important advantages (e.g. in terms of prevention of additional disputes among the countries involved) and compares favorably with the rare recourse to third party intervention in the practice of the ICJ. ${ }^{73}$

d) Simultaneously with the establishment of the Panel in June 1997, the DSB agreed to the EC's request for the initiation of an ,information-gathering procedure“ under Annex V of the

${ }^{71}$ On the dispute settlement procedures under BIT's, and their differences compared with WTO dispute settlement procedures, see: Consultation and Settlement of Disputes Between Members, Note by the WTO Secretariat for the WTO Working Group on the Relationship between Trade and Investment, WT/WGTI/W/134 of 7 August 2002.

${ }^{72}$ WTO document WT/DS54/R of 2 July 1998. This panel report has remained the only case where a violation of the TRIMS Agreement was established. In the three other WTO disputes in which claims under the TRIMS Agreement were raised, the panels declined to make a ruling on the alleged violations of the TRIMS Agreement on grounds of "judicial economy" because the panels were not persuaded that the TRIMS provisions concerned were more specific than the relevant GATT provisions examined by the panels.

${ }^{73}$ Cf. e.g. S.Rosenne, The Law and Practice of the International Court, 1997, Vol.III, at 1481-1556. 
WTO Agreement on Subsidies and Countervailing Measures. These rather unique „Procedures for Developing Information Concerning Serious Prejudice“ (Title of Annex V), which were subsequently also invoked by the USA and took place under the chairmanship of the Ambassador of Hong Kong as "representative of the DSB", require every WTO member to „cooperate in the development of evidence to be examined by a panel in a procedure under ... Article 7" (Annex V, paragraph 1). The comprehensive factual information formally established through this independent fact-finding procedure was subsequently used in the panel proceeding. The procedure illustrates the manifold advantages of institutionalized dispute settlement proceedings inside a worldwide organization with special expertise and special procedures beneficial for dispute settlement proceedings (see e.g. also the administrative, technical and legal advice given to WTO panels by the WTO operational and legal divisions).

e) In April 1998, all parties requested the Panel to review, in accordance with Article 15.2 of the DSU, certain aspects of the interim panel report that had been transmitted to the parties in March 1998. The final panel report of June 1998 notes that various factual and legal findings of the interim panel report were clarified or modified so as to take into account the comments received by all parties on the interim report. This interim panel review procedure pursuant to Article 15 of the DSU was inspired by a similar procedure in the Canada-USA Free Trade Agreement and continues to be rather unique in international dispute settlement practice compared with the procedures of international courts and arbitral tribunals.

f) The Panel findings begin with a number of preliminary rulings which the Panel had adopted at its first substantive meeting with the parties and which clarified the presence and obligations of private lawyers as representatives of Indonesia and members of its delegation; the jurisdiction of the Panel regarding certain loans provided under Indonesia's National Motor Vehicle Program; the submission and protection of business proprietary information; and the claim by Indonesia that panel findings were no longer necessary because the National Car program had been terminated. The preliminary rulings (e.g. on the right to be represented by private lawyers before a WTO panel) illustrate that WTO dispute settlement procedures offer effective remedies to deal speedily with preliminary objections in accordance with general rules of international law.

g) The Panel began its legal findings with a general statement on the methods of treaty interpretation applied by the Panel: „Throughout this report, we have based our analysis on the ordinary meaning to be given to the terms of the provisions under examination in their context and in the light of their object and purpose. In our analysis of the scope and purpose of these provisions we have also taken into account past GATT and WTO panel reports and Appellate Body reports when we considered them relevant and applicable in the present dispute. We are aware, however, that they are not binding, except with respect to resolving the particular dispute between the parties to that dispute. ${ }^{674}$ WTO panel and Appellate Body reports continue to differ from most other international dispute settlement rulings by their frequent findings on the methods of treaty interpretation (as codified in Articles 31 and 32 of the 1969 Vienna Convention on the Law of Treaties) and their emphasis on the ordinary meaning of applicable WTO rules.

h) The Panel concluded, inter alia, that the local content requirements in Indonesia's National Car Program had violated Article 2 of the TRIMS Agreement; sales taxes had

${ }^{74}$ WT/DS54/R, p.323, footnote 639. 
discriminated in favor of domestic motor vehicles in violation of Article III:2 GATT; customs duties and sales taxes had also discriminated in favor of "national cars" imported from Korea in violation of Article I of GATT; and that the EC had demonstrated by positive evidence that Indonesia had caused, through the use of specific subsidies provided pursuant to the National Car Program, serious prejudice to the interests of the EC within the meaning of Article 5(c) of the Subsidies Agreement. A number of other complaints, including a US complaint that Indonesia had breached its obligations under the TRIPS Agreement in respect of the acquisition and maintenance of trade mark rights, were rejected by the Panel. ${ }^{75}$ Compared with many other international dispute settlement proceedings which tend to focus on one or two governmental measures, the Panel report illustrates the often simultaneous examination of a large number of government measures (here: discriminatory customs duties, taxes, purchase requirements, subsidies, acquisition and maintenance of trade marks) in WTO dispute settlement proceedings in the light of a variety of multilateral agreements. On the worldwide level, such disputes over customs duties, taxes, purchase requirements, subsidies and trade marks are hardly ever submitted to the ICJ or to international arbitral tribunals since Article 23 of the DSU requires WTO members to settle their disputes under the „covered agreements“ pursuant to the DSU.

i) Unlike most other international dispute settlement proceedings, WTO panel reports are subject to appeal pursuant to Article 17 of the DSU. In the dispute over Indonesia's measures affecting the automobile industry, Indonesia did, however, not make use of this legal remedy.

j) The detailed DSU rules for the multilateral surveillance of the implementation of dispute settlement recommendations and rulings (Article $21 \mathrm{DSU}$ ) and for compensation and the suspension of concessions (Article 22) are quite unique compared with other worldwide dispute settlement procedures. Even though Indonesia had indicated its intention to comply with the dispute settlement ruling by the DSB, the EC requested that the „reasonable period of time" for the implementation of the dispute settlement findings be determined by arbitration pursuant to Article 21:3 of the DSU. The single Arbitrator determined that, taking into account Indonesia's status as a developing country and its then dire economic and financial crisis, ,the reasonable period of time for Indonesia to implement the recommendations and rulings of the DSB in this case is twelve months from the date of adoption of the Panel Report by the DSB,

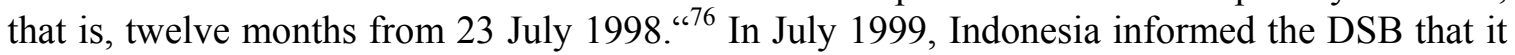
had effectively implemented the recommendations and rulings of the DSB.

Since the complaining countries had not requested reparation of injury, the Panel made no findings in this respect. According to paragraph 1 of Article 19 of the DSU,

"(w)here a panel or the Appellate Body concludes that a measure is inconsistent with a covered agreement, it shall recommend that the Member concerned bring the measure into conformity with that agreement. In addition to its recommendations, the panel or Appellate Body may suggest ways in which the Member concerned could implement the recommendations."

It remains to be clarified in future WTO legal practice whether this text, and the admonition in paragraph 2 that "the panel and Appellate Body cannot add to or diminish the rights and obligations provided in the covered agreements", exclude recourse to the general

${ }^{75}$ For details see: WT/DS54/R, p.398, paragraph 15.1.

76 Award of the Arbitrator C. Beeby, Arbitration under Article 21.3 (c) of the DSU, WT/DS54,55,59,64/12-15 of 7 December 1998. 
international law rules on state responsibility and on reparation of injury caused by violations of WTO rules.

\section{ARBITRATION WITHIN THE WTO COULD PERMIT EXTENDING THE APPLICABLE LAW AND REMEDIES BY MUTUAL AGREEMENT}

Even though most domestic legal systems limit abusive forum shopping as well as parallel and successive judicial proceedings over the same legal claims among the same parties, they recognize the legal autonomy of private parties to resolve their dispute by way of mutually agreed arbitration subject to a few exceptions for "non-arbitrable legal matters" (such as criminal law) where national courts assert exclusive jurisdiction. Similarly, the Dispute Settlement Understanding (DSU) provides for exclusive jurisdiction of WTO dispute settlement bodies " $(\mathrm{w})$ hen Members seek the redress of a violation of obligations or other nullification or impairment of benefits under the covered agreements" (Article 23:1), without precluding mutually agreed "Arbitration within the WTO" (Article 25) or unlilateral recourse to international arbitration pursuant to procedures specified in a number of other DSU provision (e.g. Articles 21.3, 22.6, 22.7, 26.1), in the WTO Agreement on Subsidies (Articles $4.11,7.10,8.5)$ as well as in the GATS (Articles XXI, XXII). ${ }^{77}$

According to Article 25:1 of the DSU, ,(e)xpeditious arbitration within the WTO as an alternative means of dispute settlement can facilitate the solution of certain disputes that concern issues that are clearly defined by both parties“. „Except as otherwise provided in this Understanding, resort to arbitration shall be subject to mutual agreement of the parties which shall agree on the procedures to be followed. Agreement to resort to arbitration shall be notified to all Members sufficient in advance of the actual commencement of the arbitration process“" (paragraph 2). The DSU does not specify whether ,arbitration within the WTO“ requires procedural links with the WTO dispute settlement system (e.g. WTO membership of all parties to the dispute, provision of ,secretarial and technical support“ by the WTO Secretariat in terms of Article 27:1 of the DSU) and/or substantive legal links (e.g. WTO law as applicable law in the dispute). The text of Article 25 suggests that these questions are left to the mutual agreement of the parties subject to review by the DSB. Article 3.5 of the DSU stipulates that "arbitration awards shall be consistent with (the covered) agreements and shall not nullify or impair benefits accruing to any Member under those agreements, nor impede the attainment of any objective of those agreements."

There has been only one arbitration under Article 25 to date. In United States - Section 110(5) of the US Copyright Act - Recourse to Article 25 of the DSU, the EC and the US requested the arbitrators to determine the level of nullification or impairment of benefits resulting from the inconsistency of Section 110(5) of the US Copyright Act with Article 9 of the TRIPS Agreement, as previously determined in a WTO panel report adopted by the DSB. ${ }^{78}$ The award of the arbitrators was notified to the DSB in November 2000 and determined that the level of EC benefits being nullified or impaired as a result of Section 110(5) amounted to 1,219,000 Euros per year. ${ }^{79}$ Following protracted negotiations and successive "status reports" by the US on its progress in implementing the WTO dispute settlement findings, the EC and US informed the DSB in June 2003 of a mutually satisfactory temporary arrangement for financial compensation of the EC copyright holders concerned.

\footnotetext{
${ }^{77}$ Cf. V.Hughes, Arbitration within the WTO, in: Ortino/Petersmann (note 22), 75-86.

${ }^{78}$ WT/DS160/R adopted on 27 July 2000.

${ }^{79}$ WT/DS160/ARB25/1.
} 
If WTO Members do not want to elaborate case-specific arbitration procedures, they can have recourse to optional standard arbitration procedures, such as the Permanent Court of Arbitration Optional Rules for Arbitrating Disputes between Two States of $1992 .{ }^{80}$ These rules have been elaborated for use in arbitrating disputes arising under public international law treaties and can be modified for use in connection with multilateral treaties. They are based on the UNCITRAL arbitration rules with changes in order to:

(a) reflect the public international law character of such disputes and state practice pertaining to such treaties;

(b) indicate the role of the Secretary-General and the International Bureau of the PCA at The Hague for the administration of such arbitration proceedings; and

(c) provide freedom for the parties to choose to have an arbitral tribunal of one, three or five persons.

The PCA publications emphasize that experience in arbitration since 1981 suggests that the UNCITRAL Arbitration Rules provide fair and effective procedures for peaceful resolution of disputes between states, or disputes involving international organizations and states, concerning the interpretation, application and performance of public international law treaties, although they were originally designed for commercial arbitration. ${ }^{81}$ The PCA rules are optional and emphasize party autonomy and flexibility. For example:

- $\quad$ the Rules, and the services of the Secretary-General and the International Bureau of the PCA, are available for use by international organizations and by all states, and are not restricted to disputes in which the states concerned are parties to either the Hague Convention for the Pacific Settlement of International Disputes of 1899 or that of 1907;

- the choice of arbitrators is not limited to persons who are listed as members and potential arbitrators on the roster of the PCA;

- $\quad$ parties have complete freedom to agree upon any individual or institution (e.g. the WTO Director General) as ,appointing authority“ if the parties cannot agree on the nomination of the arbitrators. The PCA Rules provide that the PCA Secretary-General will designate an appointing authority if the parties do not agree upon the authority, or if the authority they choose does not act;

- the PCA „Guidelines for Adapting the PCA Rules to Disputes Arising under Multilateral Agreements and Multiparty Contracts ${ }^{682}$ suggest certain modifications concerning the optional rules for naming arbitrators and sharing costs.

Mutually agreed arbitration ,within the WTO“ pursuant to Article 25 of the DSU and to the PCA optional arbitration rules could offer a number of advantages provided both parties agree. For instance:

- $\quad$ The optional rules are flexible enough to permit agreement among the parties that the arbitration be held at the WTO premises, with the WTO Secretariat serving as registry, providing secretariat and legal services, and acting as a channel of communications between the parties.

- $\quad$ The parties could also agree on applying other DSU rules (e.g. on the choice of arbitrators, periods of time, hearing of experts) on a subsidiary basis to the extent they

\footnotetext{
${ }^{80}$ For the texts see: Permanent Court of Arbitration, Basic Documents, 1998, 41-68.

${ }^{81}$ See PCA Basic Documents (note 80), at 45, 101.

${ }^{82}$ See PCA Basic Documents (note 80), at 219.
} 
are consistent with the PCA arbitration rules;

- $\quad$ The PCA optional rules on the choice of the applicable law would enable the parties to the dispute to choose not only WTO law as applicable law but also any other treaty rules (e.g. in bilateral investment treaties and WIPO conventions) and general rules of international law (e.g. on reparation of injury caused by violation of international law rules). A major advantage of "arbitration within the WTO" could thus be the avoidance of multiple complaints inside and outside the WTO; this could avoid the risk of mutually conflicting rulings if WTO panels base their findings only on WTO law and "arbitration outside the WTO" does not take into account WTO law in view of the requirement in Article 23 of the DSU to "seek redress of a violation of obligations or other nullification or impairment of benefits under the covered agreements ... (by) recourse to ... the rules and procedures of this Understanding."

- $\quad$ Article 25:3 of the DSU provides not only for the possibility of participation by third WTO members in "arbitration within the WTO". It also requires that "arbitration awards shall be notified to the DSB and the Council or Committee of any relevant agreement where any Member may raise any point relating thereto." Article 3:5 of the DSU stipulates that "all solutions to matters formally raised under the consultation and dispute settlement provisions of the covered agreements, including arbitration awards, shall be consistent with those agreements and shall not nullify or impair benefits accruing to any Member under those agreements, nor impede the attainment of any objective of those agreements." The discussion of arbitration awards in the DSB would not affect their legally binding effect among the parties to the dispute, but could prove beneficial for clarifying "interface problems" between WTO law and other fields of international law.

- $\quad$ According to Article 25:4 of the DSU, "Articles 21 and 22 of this Understanding shall apply mutatis mutandis to arbitration awards." Arbitration "within the WTO" therefore offers another adavantage over "arbitration outside the WTO", i.e. the availability of the DSU rules on multilateral surveillance of implementation of dispute settlement rulings, compensation and suspension of concessions as "temporary measures available in the event that the recommendations and rulings are not implemented within a reasonable period of time" (Article 22:1). Article 23 of the DSU on "Strengthening of the Multilateral System", notably the prohibition of unilateral determinations of violations of WTO rules and the requirement to respect WTO dispute settlement procedures and dispute settlement rulings, likewise applies to "an arbitration award rendered under this Understanding" (paragraph 2).

- Compared with the DSU rules, the PCA optional arbitration rules offer additional provisions e.g. on interpretation and correction of awards; additional awards as to claims presented in the arbitral proceedings but omitted from the award; determination and apportionment of the costs of arbitration in the award.

This short survey suggests that, for certain categories of disputes, the possibility of "expeditious arbitration within the WTO as an alternative means of dispute settlement" (Article $25 \mathrm{DSU}$ ) could be more advantageous - in terms of dispute settlement procedures, applicable substantive international law and available legal remedies- than normal WTO panel and appellate review procedures. 


\section{SIMULTANEOUS OR SUCCESSIVE RECOURSE TO THE ICJ AND TO WTO DISPUTE SETTLEMENT PROCEDURES FOR JUDICIAL REVIEW OF RELATED LEGAL CLAIMS}

As many WTO members have accepted the jurisdiction of the ICJ pursuant to Article 36 of the ICJ Statute, an intergovernmental dispute in the WTO may be linked to related legal claims and dispute settlement proceedings in the ICJ. For instance, in the maritime delimitation dispute between Nicaragua, Colombia and Honduras, Nicaragua submitted its maritime dispute with Honduras to the ICJ in December 1999; Colombia requested WTO consultations with Nicaragua in January 2000, as well as the establishment of a WTO panel in May 2000, in order to examine whether Nicaragua's trade sanctions in response to the maritime dispute were inconsistent with its GATT obligations ${ }^{83}$; Honduras requested WTO consultations over the alleged inconsistencies with GATT and GATS of Nicaragua's counter-measures in June 2000 and reserved its third-party rights to intervene in the WTO panel proceeding among Nicaragua and Colombia. ${ }^{84}$ In such parallel dispute settlement proceedings in the WTO and in the ICJ, the legal findings of one court (e.g. on the legal justifiability of trade restrictions under the general international law rules on state responsibility and counter-measures) may be influenced by the legal findings in the other court (e.g. on the violation of Nicaragua's rights under the law of the sea).

Concurrent trade-related investment disputes in the WTO and the ICJ appear unlikely for a number of reasons. In contrast to the increasing number of international investment disputes under ICSID and NAFTA dispute settlement rules, states remain very reluctant to submit international investment disputes to the ICJ and to the classical international law rules on the treatment of aliens and the protection of foreign-owned property: Similar to the only few investment disputes submitted to the Permanent Court of International Justice (PCIJ) - leading to the 1926 and 1928 judgments of the PCIJ in the Chorzow Factory Case, the 1925 and 1927 judgments in the Mavrommatis Concession Cases, and the 1934 judgment in the Oscar Chinn Case -, the 1970 judgment by the ICJ in the Barcelona Traction Case and the 1989 judgment in the ELSI Case are illustrative of the fact that the ICJ seems to be perceived by most foreign investors and their home governments as a sub-optimal legal framework for the settlement of modern investment disputes. ${ }^{85}$

Even though many WTO Members have accepted the jurisdiction of the ICJ under multilateral WIPO conventions on the protection of intellectual property rights, no intellectual property dispute has ever been submitted to the ICJ to date. Yet, some of the already more than 20 dispute settlement proceedings under the TRIPS Agreement ${ }^{86}$ involved legal claims based e.g. on the Paris Convention on Industrial Property and the Bern Convention for the Protection of Literary and Artistic Works that could have also been submitted to the ICJ pursuant to the dispute settlement provisions in these WIPO conventions.

Several other international agreements providing for the dispute settlement jurisdiction of the ICJ (e.g. pursuant to Articles 84 and 86 of the 1944/1968 Convention on International Civil Aviation) could be relevant also for related dispute settlement proceedings in the WTO

${ }^{83} \mathrm{WT} / \mathrm{DS} 188$. The panel has not been composed.

${ }^{84}$ WT/DS201.

${ }^{85}$ See above note 55 and related text, as well as M.Sornarajah, The Settlement of Foreign Investment Disputes, 2000, chapter 10. On the decreasing role of the ICJ for the settlement of international economic disputes see: E.U.Petersmann, Dispute Settlement in International Economic Law - Lessons for Strengthening International Dispute Settlement in Non-Economic Areas, in: Journal of International Economic Law 2 (1999), $189-248$, at 202-204.

${ }^{86}$ These TRIPS disputes are analyzed in the contributions by F.Abbott and M.Matsushita to: Ortino/Petersmann (note 22), 421-473. 
(e.g. on international air transport services). WTO law includes only few provisions dealing explicitly with such jurisdictional overlaps. For instance, Section 2 of the GATS Annex on Air Transport Services provides that " $(\mathrm{t})$ he Agreement, including its dispute settlement procedures, shall not apply to measures affecting (a) traffic rights, however granted; or (b) services directly related to the exercise of traffic rights". A different kind of regulation of jurisdictional problems is to be found in Section 4: "The dispute settlement procedures of the Agreement may be invoked only where obligations or specific commitments have been assumed by the concerned Members and where dispute settlement procedures in bilateral and other multilateral agreements or arrangements have been exhausted." Article XXII:3 of GATS offers an example for the possibility of international arbitration in the case of competing jurisdictions for consultations (Article XXII) and dispute settlement (Article XXIII):

\begin{abstract}
"A Member may not invoke Article XVII, either under this Article or under Article XXIII, with respect to a measure of another Member that falls within the scope of an international agreement between them relating to the avoidance of double taxation. In case of disagreement between Members as to whether a measure falls within the scope of such an agreement between them, it shall be open to either Member to bring this matter before the Council for Trade in Services. The Council shall refer the matter to arbitration. The decision of the arbitrator shall be final and binding on the Members."
\end{abstract}

If disputes outside the WTO (e.g. in the ICJ) also involve rights and obligations under WTO law, Article 23:1 of the DSU requires WTO members to "seek the redress of a violation of obligations or other nullification or impairment of benefits under the covered agreements ... (by) recourse to ... the rules and procedures of this Understanding." WTO law would not prevent the submission of disputes over related, other international treaty obligations to the ICJ. If the dispute before the WTO dispute settlement bodies would be limited to WTO law and the dispute before the ICJ would relate to other international treaty rights and obligations, the simultaneous examination of all treaty obligations may be in the interest of both parties in order to reach a comprehensive settlement of the dispute. In case of objections by the defending country to "arbitration within the WTO" on all these treaty rights and obligations, the complaining country may unilaterally submit the "WTO dispute" to WTO panel proceedings and initiate ICJ proceedings for the protection of its other international treaty rights.

Neither the DSU (e.g. Article 23 on exclusive jurisdiction of the WTO on disputes over WTO law) nor general international law rules (e.g. on litis pendens) would seem to stand in the way of such simultaneous or successive WTO and ICJ dispute settlement proceedings on different, yet related legal claims. In order to avoid incoherent dispute settlement findings, some coordination among concurrent and related dispute settlement proceedings in different fora is desirable. While WTO panel and Appellate Body reports have repeatedly referred to the jurisprudence of the ICJ, no ICJ judgment has so far referred to WTO law or WTO jurisprudence. The differences in the procedures for the settlement of disputes in the ICJ and in the WTO could hinder such practical coordination. For example, the procedural requirement of prior exhaustion of local remedies - which was emphasized by the ICJ in its ELSI-judgment has never been applied in GATT and WTO dispute settlement practice. ${ }^{87}$ In contrast to ICJ procedures, WTO dispute settlement procedures tend to be much quicker, are not limited to sovereign states, favor third-party intervention, and permit amicus curiae briefs. If, as in the case of many BITs, an international investment treaty provides for jurisdiction of an arbitral tribunal rather than the ICJ, some of these procedural differences and potential problems could be avoided by mutual agreement among the parties to the dispute, for instance on the

${ }^{87}$ Cf. E.U.Petersmann (note 6), 240-244. 
composition of the WTO panel and of the arbitral tribunal by the same arbitrators and the application of coherent dispute settlement procedures.

\section{SIMULTANEOUS OR SUCCESSIVE RECOURSE TO WTO, ICSID OR WIPO DISPUTE SETTLEMENT PROCEDURES FOR JUDICIAL REVIEW OF RELATED LEGAL CLAIMS}

Instead of requesting its home state to espouse and defend the legal claims of its nationals by means of intergovernmental dispute settlement proceedings in the WTO, in the ICJ or under intergovernmental arbitration procedures, a foreign private investor, "service supplier" protected under the GATS, or an intellectual property holder protected under the TRIPS Agreement might prefer to "de-politicize" and "control" its dispute with a foreign government so as to avoid adverse effects of intergovernmental dispute settlement proceedings on its future business in the host country. If, as in the case of many BITs, the investment agreement provides for either intergovernmental arbitration or ,mixed investor-State arbitration" pursuant to ICSID arbitration procedures, the private complainant may directly invoke the "ICSID clause“ in the BIT and submit its investment dispute to investor-State arbitration pursuant to ICSID procedures. The increasingly used ICSID arbitration proceedings offer various advantages compared with intergovernmental arbitration, adjudication or WTO panel proceedings. For example:

- ICSID conciliation (e.g. on the use of revision clauses in investment contracts) or ICSID arbitration procedures between the host state and the foreign investor can be kept confidential. ${ }^{88}$ By avoiding the frequent politicization of intergovernmental disputes, ICSID procedures may increase the prospects for a mutually agreed solution of the dispute that safeguards the continued future operation of the investments and the longterm interests of both parties. ${ }^{89}$ The majority of the more than 60 conciliation and arbitration cases registered by ICSID tend to conclude with settlements by the parties on agreed terms before the rendering of an award.

- $\quad$ The jurisdiction of ICSID for "any legal dispute arising directly out of an investment" (Article 25) is broad since the definition of the covered ,investment disputes" is left to agreement among the parties. The „Additional Facility Rules“ of 1978 authorize the ICSID Secretariat to administer also conciliation and arbitration proceedings between states and national of other states which fall outside the scope of the ICSID Convention if one of the parties is not an ICSID member state or a national of an ICSID contracting state, or if the dispute does not arise directly out of an investment provided it is not an ordinary commercial dispute.

- $\quad$ Prior exhaustion of local remedies may not be necessary for ICSID arbitration (cf. Article 26 of the 1965 ICSID Convention). ICSID arbitration may therefore lead to much quicker international judgments compared with investment disputes before the ICJ which, e.g. in the ELSI case, might be admissible only after exhaustion of local remedies during many years of court proceedings in the host country.

- In the absence of agreement to the contrary, an ICSID tribunal ,shall apply the law of the Contracting State party to the dispute (including its rules on the conflicts of laws) and such rules of international law as may be applicable" (Article 42:1 ICSID

\footnotetext{
${ }^{88}$ Note that the ICSID Secretariat is a neutral secretariat which assists in the administration of conciliation and arbitration proceedings but does not itself engage in conciliation or arbitration.

${ }^{89}$ Cf. L.M.Hager/R.Pritchard, Deal Mediation: How ADR Techniques Can Help Achieve Durable Agreements in the Global Markets, in: ICSID Review Foreign Investment Law Journal 1999, 1-16.
} 
Convention). International law may be invoked not only to fill lacunae in the applicable host state law. International law prevails in case of conflicts with the national law of the host state. Taking into account also the applicable municipal law might avoid legal discrepancies as in the ICJ's ELSI judgment where the requisitioning of a foreign investment in clear violation of domestic law was held lawful under a FCN Treaty designed to protect foreign investors. ${ }^{90}$

- $\quad$ ICSID awards ,shall be binding on the parties and shall not be subject to any appeal or to any other remedy except those provided for in this Convention" (Article 53:1 ICSID Convention). Unlike private commercial arbitration which tends to be subject to control and annulment by national courts in case of grave irregularities, ICSID arbitration is self-contained in the sense that annulment procedures and other legal remedies against ICSID judgments are reduced to the mechanisms offered by the ICSID Convention itself. $^{91}$ Moreover, „(e)ach Contracting State shall recognize an award rendered pursuant to this Convention as binding and enforce the pecuniary obligations imposed by that award within its territories as if it were a final judgment of a court in that State" (Article 54:1). However, ,nothing in Article 54 shall be construed as derogating from the law in force in any Contracting State relating to immunity of that State or of any foreign State from execution" (Article 55).

Even though several among the more than twenty multilateral treaties on intellectual property administered by WIPO provide for the settlement of disputes by the ICJ, no intellectual property dispute was ever submitted to the ICJ. The 1995 WIPO Draft Treaty on the Settlement of Disputes among States in the Field of Intellectual Property ${ }^{92}$ likewise continues to be opposed by the USA and other developed countries. The WIPO Arbitration and Mediation Center was established in 1994 in response to a perceived need for specially designed intellectual property dispute resolution procedures based upon mediation, arbitration or "expedited arbitration" rules which are open to all persons regardless of nationality, residence or other links with WIPO member states. ${ }^{93}$ Also a state entity "may be party to a dispute submitted to a procedure administered by the Center, provided that the State entity has, like any other party to a dispute that is referred to the Center, validly expressed its consent in writing to the reference of the dispute to such a procedure." 94

Since 2000, the newly developed WIPO "electronic dispute resolution" for disputes over internet domain names ${ }^{95}$ has led to more than thousand dispute settlement rulings on abusive registration of domain names on the Internet. The so far infrequent recourse to WIPO mediation and arbitration rules ${ }^{96}$ seems to be due to the fact that, although the rules are said to

${ }^{90}$ For a criticism of the ELSI judgment on this point see above F.A.Mann, note 55.

${ }^{91}$ For the criticism of the - in some cases (notably Klöckner v. Cameroon and Amco v. Indonesia) excessive - use of the annulment procedure under Article 52 of the ICSID Convention see: A.Broches, On the Finality of Awards, in: 8 ICSID Review 1993, 92 et seq. Since the case MINE v. Guinea, this earlier trend of asserting a quasi appellate review authority has been reversed.

${ }_{92}$ Cf. WIPO document SD/CE/VII/2 of 10 February 1995.

93 See: WIPO Mediation Rules, WIPO Arbitration Rules, WIPO Expedited Arbitration Rules, Recommended Contract Clauses and Submission Agreements, WIPO 1995.

94 See: The Services of the WIPO Arbitration Center, WIPO 1996, at 18. Hence, "claimant" and "respondent" in terms of the mediation and arbitration rules may include not only private parties but also state entities. Cf. also: F.Abbott/T.Cottier/G.Gurry, The International Intellectual Property System, Vol.II 1999, at 1738.

95 See: F.Gurry, The Dispute Resolution Services of the WIPO, in: Journal of International Economic Law 1999, 385-398.

${ }^{96}$ See e.g. the case reported in: Activities of the WIPO Arbitration and Mediation Centre, December 1999. The dispute settlement has remained confidential. 
accommodate the specific characteristics of intellectual property disputes (e.g. need for expert opinions, qualified arbitrators, admission of site visits and experiments) and to offer many advantages (including savings of time and cost, party autonomy for choosing the language and applicable law), most private disputes over intellectual property rights continue to be settled in national courts or through commercial arbitration based on e.g. UNCITRAL or ICC rules which differ little from the WIPO arbitration rules. ${ }^{97}$ Since many national legal system have been reluctant vis-à-vis the submission of intellectual property disputes to arbitration, there also continues to be uncertainty amongst practitioners regarding the arbitrability of intellectual property disputes and the recognition and enforcement of such arbitral awards. ${ }^{98}$

"Mixed" mediation or arbitration procedures between private and governmental entities in the WIPO could offer similar advantages as ICSID procedures, compared with the more politicized WTO dispute settlement mechanisms. Yet, the already more than 20 WTO dispute settlement procedures under the TRIPS Agreement suggest that multinational firms and other private entities seem to favor to petition their home government to initiate complaints over non-compliance with TRIPS obligations in the WTO. EC and US trade legislation provide explicitly for such private remedies in response to other countries' non-compliance with TRIPS obligations. Also WTO member governments seem to prefer the compulsory jurisdiction and effective procedures of the WTO dispute settlement system rather than "mixed" or intergovernmental dispute settlement procedures in WIPO.

This current attitude could, however, change if the increasing number of intellectual property disputes in the WTO should run into problems (e.g. in view of the limited scope of WTO law, of legal remedies and secretarial resources in the WTO), or if the commercial interests of private complainants in preserving ongoing business relationships might prompt a preference for more discreet, mixed dispute settlement procedures. Despite its so far limited case docket, the WIPO Arbitration Center seems to be innovating and influencing the procedures for the settlement of certain categories of intellectual property disputes. The increasing recourse to ICSID dispute settlement procedures suggests that there might develop a similar demand for mixed arbitration or mediation of intellectual property disputes with governmental authorities where both parties may prefer a speedy and confidential ad hoc solution of their dispute. The arguments in favor of decentralizing international investment disputes also hold for intellectual property disputes.

\section{TIME FOR PROMOTING RULE OF LAW BY REDUCING THE INCONSISTENCIES BETWEEN INTERNATIONAL AND DOMESTIC JUDICIAL REVIEW OF CONTINGENT PROTECTION MEASURES}

Numerous WTO Agreements include guarantees of private access to domestic courts. Article 13 of the Anti-Dumping Agreement, for example, requires Members to maintain judicial, arbitral or administrative tribunals to provide prompt and independent review of administrative actions relating to final determinations and reviews of determinations. In the United States, parties that were involved in a final determination or the final results of a review may have recourse to independent tribunals to challenge such determination of either the US Department of Commerce or the US International Trade Commission. ${ }^{99}$ Specifically, parties may challenge the final agency determination before the US Court of International Trade, the

\footnotetext{
${ }^{97}$ Cf. H.Van Houtte, The Law of International Trade, 1995, 383-414, according to whom the specialized WIPO procedures are, in reality, not very specialized at all (at 404-406).

${ }^{98}$ Cf. J. Werner, Intellectual Property Disputes and Arbitration, in: Journal of World Intellectual Property $1998,841-886$, at 844.

9919 U.S.C. $\$ 1516 \mathrm{a}(2003)$.
} 
Court of Appeals for the Federal Circuit, and the US Supreme Court. Alternatively, in certain cases involving merchandise from Canada or Mexico, parties have the option of appearing before a dispute panel established under Chapter 19 of NAFTA.

Parallel or successive dispute settlement proceedings challenging the same import restrictions, anti-dumping determinations or countervailing duty determinations in WTO dispute settlement proceedings, in regional courts (like the EC Court of Justice), in NAFTA panels and domestic courts have become frequent in international trade relations. Yet, among all the WTO Agreements, only the Agreement on Government Procurement explicitly requires the domestic courts to apply, and examine violations of, the relevant WTO rules (cf. Article XX). ${ }^{100}$ As both the EC as well as the US legislation on domestic implementation of WTO law limit the direct application of WTO rules in domestic courts ${ }^{101}$, many domestic court decisions ignore WTO rules and WTO dispute settlement rulings, just as WTO dispute settlement rulings are sometimes inconsistent with domestic court decisions (e.g. on "dumping" or "injury" caused by dumped imports). Such incoherence between domestic, regional and WTO law and WTO jurisprudence undermines legal security and the legitimacy of courts and increases international transaction costs. ${ }^{102}$ For example, the more than ten successive GATT and WTO panel, appellate and arbitration reports, since 1993, on the inconsistency with GATT and GATS of the EC's import restrictions on bananas were preceded, paralleled or followed by more than 45 EC Court judgments that tended to ignore the violations of the relevant GATT and WTO rules as well as the WTO dispute settlement rulings against the EC. ${ }^{103}$ At the national level (e.g in Germany), adversely affected banana importers challenged the EC's illegal import tariffs on bananas in the tax courts, the illegal import quotas and refusals of import licences for bananas in administrative courts, and the excess of the EC's limited powers for manifestly illegal restrictions of individual freedom of trade in violation of GATT/WTO law and EC law (e.g. Article 300, ex-228:7 EC) before the German Constitutional Court.

Even though these national, regional and worldwide dispute settlement findings were directed against the same EC import restrictions, only a few national court decisions in Germany took into account the GATT and WTO dispute settlement findings and refused applying the EC import restrictions in view of their legal inconsistency with WTO law and the legal primacy of WTO law over regulations and decisions adopted by the EC Council and the EC Commission. ${ }^{104}$ By contrast, in the more than 45 proceedings before the EC Court of Justice against the EC import restrictions on bananas, the EC Court persistently ignored the GATT and WTO dispute settlement findings as well as the EC Treaty obligations (e.g. in Article 300:7 EC Treaty) to construe and apply EC law in conformity with international law. ${ }^{105}$

${ }^{100}$ On the so far only two WTO panel proceedings under the Agreement on Government Procurement see Gabilondo (note 29).

${ }^{101}$ Cf. Petersmann (note 6), 18-23; J.Jackson/A.Sykes (note 12).

102 For examples of mutually inconsistent NAFTA and GATT/WTO dispute settlement findings concerning the same trade measures, and on the frequent submission of trade disputes among NAFTA member states to GATT and the WTO rather than to NAFTA panels, see Shany (note 16), 54-57.

${ }^{103}$ For overviews and analyses of these GATT, WTO and EC disputes see the case-study by F.Weiss, Manifestly Illegal Import Restrictions and Non-Compliance with WTO Dispute Settlement Rulings: Lessons from the Banana Dispute, in: Petersmann/Pollack (note 24), 121-139; J.Cascante/G.G.Sander, Der Streit um die EG Bananenmarktordnung, 1999.

${ }^{104}$ Cf. E.U.Petersmann, Darf die EG das Völkerrecht ignorieren? In: European Journal of Business Law (EuZW) 1997, 325-331.

${ }^{105}$ For a criticism of the frequent "judicial protectionism" by the ECJ and its often introverted neglect of international law see the former ECJ judge P.Pescatore, Jurisprudence de la Cour de Justice en matière de Politique Commercial, in: La Place de l'Europe dans le Commerce Mondial, Institut Universitaire International Luxembourg, 1994, at 445, 458 ("la Cour ignore volontairement la réalité et la matérialité des règles du commerce 
Since most domestic legal systems require judges to construe domestic law in conformity with international law, many international disputes could be avoided if domestic judges would take more seriously their task to defend the rule of law and protect domestic citizens also against protectionist violations of international guarantees of freedom and non-discrimination, such as those in WTO law.

\section{Need for Distinguishing International Trade Disputes According to their Underlying Conflicts of Interests and for Promoting Legal Consistency between International and Domestic Dispute Settlement Proceedings}

The examination by a government of how to react to the complaint by another government, or by a private complainant, requires an examination of the conflicts of interests and relevant rules and procedures involved. Optimal dispute prevention and dispute settlement strategies must target the source of the conflict of interests (section 1 below). Five different categories of international trade disputes can be distinguished according to their underlying conflicts of private and public interests; the optimal dispute prevention and dispute settlement rules and procedures are likely to differ for each major category of international trade dispute (section 2). The successful recourse to mediation and conciliation in recent WTO practice raises the question of whether, for certain kinds of primarily political disputes, alternative dispute resolution methods should not be institutionalized more effectively in the WTO context (section 3). The ongoing "legalization" and "judicialization" of international trade relations calls for stronger horizontal and vertical "judicial networks" so as to render international and domestic dispute settlement proceedings legally more coherent and strengthen rule of law and prevention or settlement of international disputes at the optimal national and/or international levels (section 4).

\section{OPTIMAL DISPUTE PREVENTION AND DISPUTE SETTLEMENT STRATEGIES MUST TARGET THE SOURCE OF THE CONFLICT OF INTERESTS}

International economic relations and international economic law evolve through autonomous decisions by private and public economic operators (e.g. investors, producers, traders, consumers, government procurement agencies) and "multi-level governance" by transnational corporations, local and national governments, regional organizations (like the EC) and worldwide institutions (like the WTO). International economic disputes reflect conflicts among these diverse private and public, national and international interests. Just as negotiations and rule-making at the international level among governments are preceded, influenced and followed by negotiations between government representatives, parliamentarians and domestic constituencies at national levels, dispute prevention and dispute settlement rules and procedures must be designed such that they intervene at the optimal level directly at the source of the conflict of interests. Hence, rules and procedures for the prevention and settlement of international trade disputes are needed in national laws, at the level of international relations among states, in transgovernmental relations among government agencies (e.g. international cooperation among competition authorities), in transnational relations among private economic actors (e.g. private commercial arbitration), as well as in "mixed" relations among private and foreign public actors (e.g. investor-state arbitration pursuant to ICSID procedures). The more

international"), as well as the conclusions of Advocate-General G.Tesauro in the Hermès-Case C-53/96 of 13 November 1997, ECJ Reports 1998, 3603-3637. 
legitimate and the more coherent these national, international and transnational dispute prevention and dispute settlement rules are, the more effective they are likely to be.

a) Many International Trade Disputes Involve Conflicts Among Private Interests $\underline{\text { Rather than Among State Interests }}$

The classic international law paradigm of a dispute among states over conflicting national interests (e.g. in the determination of a territorial boundary) is misleading for many international trade and investment disputes which involve the interests of private economic operators. Most international trade disputes have their origin in domestic conflicts of interests inside states, notably in conflicts among protectionist self-interests of import-competing producers and the liberal trade interests of consumers and exporters. All WTO Members have committed themselves to the legal and judicial protection of the long-term citizen interests in reciprocal trade liberalization, non-discriminatory conditions of competition and rule of law, subject to comprehensive safeguard clauses and "public interest exceptions" permitting restrictions of trade if, for instance, imports "cause or threaten serious injury to domestic producers" (Article XIX GATT), or import restrictions are necessary for the protection of noneconomic public interests (Articles XX, XXI GATT). In constitutional democracies, conflicts of interests among producers, traders and consumers should be decided by domestic courts in accordance with the applicable national and international rules ratified by domestic parliaments, including WTO law.

\section{b) $\quad$ Choosing Among Dispute Prevention and Dispute Settlement}

The distinction between "prevention" and "settlement" of a dispute is fluid and depends on the perception of the parties. Many foreign policy conflicts (e.g. over EC import restrictions on genetically modified organisms) were, for several years, deliberately left "legally unsettled" in the hope of negotiating an agreed solution. For example, in the GATT/WTO dispute over the EC import prohibitions on hormone-fed beef, the United States refrained from requesting a dispute settlement panel until it succeeded in replacing the 1979 Tokyo Round Agreement on Technical Barriers to Trade by the more stringent rules (e.g. on science-based risk assessment procedures) in the WTO Agreement on (Phyto)Sanitary Standards. By first renegotiating the relevant substantive rules, the United States ensured the success of its subsequent WTO complaint. ${ }^{106}$ The Doha Ministerial Declaration on Access to Medicines of November 2001, and the subsequent WTO waiver granted from Article 31(f) of the WTO Agreement on TradeRelated Intellectual Property Rights (TRIPS) in August 2003, are further illustrations of successful dispute prevention through negotiation and clarification of WTO rules in a manner rendering WTO dispute settlement proceedings challenging compulsory licenses, parallel imports of low-priced medicines, or importation of generic drugs more unlikely. ${ }^{107} \mathrm{~A}$ few months prior to the Doha Ministerial Declaration, Brazil and the United States had negotiated a mutually satisfactory solution that enabled the suspension of the WTO panel proceeding on the US complaint that the "local working" requirement and threat of compulsory licenses in Brazil's patent legislation amounted to a violation of GATT Article III and Articles 27 and 28 of the TRIPS Agreement. ${ }^{108}$

\footnotetext{
${ }^{106}$ Cf. the Panel and Appellate Body reports in WT/DS26/R (1997) and WT/DS26/AB/R (1998).

${ }^{107}$ Cf. Mini-Symposium on Health and the WTO, in: Journal of International Economic Law 5 (2002), $821-939$

${ }^{108} \mathrm{Cf}$. the various WT/DS199 documents.
} 
c) Choosing Among Different Negotiation Strategies

Governments, like private negotiators, have to choose between "power-oriented" negotiations (with explicit or implicit reference to their relative power and "bargaining chips") and "rule-oriented" negotiations or adjudication aimed at enforcement of rules that were previously agreed by both parties. ${ }^{109}$ Negotiation theories ${ }^{110}$ distinguish three different kinds of negotiation strategies:

(1) "soft bargaining over positions" when a negotiator wants to avoid personal conflict with the other side and so makes concessions readily in order to reach agreement and an amicable resolution;

(2) "hard bargaining over positions" when a negotiator sees the divergent positions as a contest of wills and wants to win by taking extreme positions and holding out longer; "principled negotiations" in which a negotiator looks for mutual gains and a "wise agreement" by separating the personal relationship from the substantive problem, focusing on interests (rather than positions), inventing options for mutual gain, and by insisting that the agreement must reflect some fair standard independent of the naked will of either side. "Positional bargaining" risks not only to be power-oriented and to damage the personal relationship between the parties but to lead also to unwise agreements with high implementation costs. By separating the people from the problem, "principled negotiations" help to maintain a mutually beneficial relationship among the parties and to base the substantive agreement on objective principles that reflect the agreed long-term interests of all parties and can serve as fair standards for settling disputes over conflicts among their short-term interests.

The appropriate "legal strategy" may depend not only on the governmental determination of the "public interest" but also on the private interests and factual, legal and financial in-puts from private actors involved in the economic dispute. The interests may go beyond an individual dispute so as to secure a "package deal" resolving a number of different disputes, or may reflect systemic interests in judicial clarification of controversial rules so as to prevent future disputes. In constitutional democracies, governments are required to promote the "public interest" as defined by the constitutional rights of their citizens, by democratic legislation, general consumer welfare, consumer-driven competition and non-discriminatory regulation of "market failures" as well as "government failures".

\section{FIVE DIFFERENT CATEGORIES OF INTERNATIONAL TRADE DISPUTES}

The habit of lawyers to distinguish "GATT disputes" from GATS-, TRIPS-, ICJ-, ICSID-, WIPO-, EC- and other international economic disputes (e.g. in regional courts and private arbitration) is due to the fact that the relevant procedures and substantive rules for the prevention or settlement of a dispute differ depending on the applicable law. Legal expertise required for the proper conduct and evaluation of disputes in these diverse areas of international economic law differs considerably. No single international lawyer can follow the vast jurisprudence and legal practice in all these areas. Legal experts specialized in ICJ, ICSID

109 On this distinction see: J.H.Jackson, The World Trading System. Law and Policy of International Economic Relations, 2nd ed. MIT Press Cambridge 1997, at 109; E.U.Petersmann (note 6), 66-70.

${ }^{110}$ In addition to R.Fisher/W.Ury (above note 5) see: R.Fisher/E.Kopelman/A.Kupfer-Schneider, Beyond Machiavelli, 1994; R.Fisher/S.Brown, Getting Together. Building a Relationship that Gets to Yes, Boston 1988; J.Kaufmann, Conference Diplomacy, $2^{\text {nd }}$ ed. UNITAR 1988. 
or WIPO dispute settlement proceedings tend to be different from those specialized in WTO, NAFTA or EC disputes. In most developed and less developed countries, governments involved in such dispute settlement proceedings can no longer rely exclusively on "in house" legal services in their national ministries of justice, economic affairs or foreign affairs. Even the EU and US with their vast legal resources often include specialized outside lawyers (e.g. from private law firms or academia) into their "legal teams" preparing litigation strategies, written submissions, rebuttals, and rejoinders.

In order to design effective dispute prevention and dispute settlement strategies, different kinds of economic disputes must be distinguished according to the public and private interests involved. ${ }^{111}$ For example:

a) "Secondary Disputes" over Prohibited Trade Discrimination: Domestic Legal and Judicial Remedies Can Prevent Intergovernmental Disputes

Most WTO disputes are about discriminatory import restrictions or export subsidies that are inconsistent with the self-imposed WTO obligations of governments (e.g. GATT Articles I-III) and, according to welfare economics, reduce consumer welfare of domestic citizens. Even though WTO law permits various kinds of import protection (e.g. pursuant to GATT Articles II, VI and XIX) and domestic subsidies, governments are often pressured to resort to prohibited and non-transparent forms of trade protection for the benefit of powerful domestic interest groups in exchange for political support (e.g. for election campaigns and other domestic legislation). Such intergovernmental disputes over welfare-reducing trade discrimination can be described as "secondary conflicts among states" that arise if, for domestic political reasons, governments fail to use "first best policy instruments" at home, such as non-discriminatory internal regulation of "market failures" and "public goods".

Reciprocal WTO commitments and domestic implementation and enforcement of WTO rules can assist governments in overcoming the "producer biases" of national trade policymaking by committing governments to reciprocal guarantees of rule of law and protection of general citizen welfare. In constitutional democracies, such government failures can be prevented most effectively by empowering adversely affected citizens to defend the rule of law by enforcing precise and unconditional, democratically approved WTO prohibitions of trade discrimination in domestic courts. As confirmed by the decentralized judicial application and enforcement of the EC's common market rules, national judges have long-standing expertise in enforcing such prohibitions of discrimination in economic and other fields of law (e.g. human rights law, labor law, constitutional law). Many GATT and WTO dispute settlement proceedings could be prevented by empowering domestic citizens and judges to protect the rule of law against discriminatory interest group politics in violation of the democratically approved, national and international legal obligations of governments.

b) "Primary Disputes" over Non-Discriminatory Internal Regulation: Need for Judicial Deference at National and International Levels

The increasing number of "regulatory disputes" over non-discriminatory internal (product-, production-, tax-, health-, environmental-) regulations reflect different conflicts of interests. Economic and democratic theory explain that non-discriminatory internal regulations may legitimately differ from country to country as long as they comply with relevant nondiscrimination, necessity and other legal requirements (e.g. of human rights and WTO law).

111 Cf. E.U.Petersmann, Prevention and Settlement of Transatlantic Disputes, in: Petersmann/Pollack (supra note 24), 34 et seq., 582 et seq. 
Respect for democracy, "sovereign equality" of states, "regulatory competition" and international regulatory cooperation tend to be first-best policy instruments, requiring "negative" and "positive comity", mutual recognition of equivalent standards (e.g. pursuant to the WTO Agreements on Technical Barriers to Trade, Sanitary Standards, Article VII GATS), or internationally agreed harmonization of divergent national rules. Such intergovernmental disputes require national and international judicial deference vis-à-vis legitimate, democratic rule-making. As foreign interests tend to be under-represented in such "behind the border regulation", related disputes often involve claims of indirect de facto discrimination prohibited by WTO rules (e.g. in GATT Article III, GATS Articles II,XVII). ${ }^{112}$ Yet, in case of nondiscriminatory measures (e.g. prohibition of genetically modified organisms), there may be "primary conflicts of interests" due to legitimate regulatory and democratic divergences (e.g. more science-based health standards in the USA than in Europe) that often cannot be overcome through international adjudication.

c) "High Policy Disputes" to be Prevented and Settled through Political Negotiations

International dispute settlement practice (e.g. in GATT and WTO) suggests that there may be "high policy disputes" whose political dimensions are inappropriate for judicial proceedings. The "security exceptions" in GATT/WTO law (e.g. GATT Article XXI) are drafted and interpreted so broadly that economic sanctions for foreign policy reasons (e.g. sanctions in response to expropriations of foreign property in Cuba, apartheid policy in South Africa, military occupation of the Malvinas island by Argentina) have been rarely challenged in GATT/WTO dispute settlement proceedings. The 1984 GATT panel report on Nicaragua's complaint against US import restrictions imposed for foreign policy reasons concluded that the import restrictions violated Article XIII:2; as the US had not invoked any GATT exceptions, the panel report did not examine whether the violation of Article XIII:2 could be justified under GATT Article XXI. ${ }^{113}$ Both parties recognized that Nicaragua's rights to take countermeasures under GATT Article XXIII:2 were not practical in view of the US trade embargo, and that the termination of the US sanctions depended on a resolution of the foreign policy conflict.

In the WTO dispute over the US' "Helms/Burton legislation" extending US sanctions against Cuba vis-à-vis companies from the EC that had engaged in business transactions with Cuba, the EC requested the establishment of a WTO dispute settlement panel after bilateral consultations had failed to settle the dispute. The EC thereby strengthened its negotiation position by demonstrating that a WTO dispute settlement ruling against the US was a credible "BATNA". Afterwards, the EC preferred to negotiate - "in the shadow of the law" - a bilaterally agreed settlement of the dispute as part of a broader "Understanding with Respect to Disciplines for the Strengthening of Investment Protection" which both parties proposed for inclusion into a multilateral investment agreement. ${ }^{114}$ Thus, by drawing attention to legally available alternatives and by transforming the bilateral dispute into a multilateral dispute prevention strategy, the EC succeeded in elaborating a mutually beneficial, political solution.

Third party adjudication in the WTO may be inappropriate also in areas of broad foreign policy discretion. Until recently ${ }^{115}$, for instance, less-developed countries (LDCs) never

${ }^{112}$ See the contribution by F. Ortino to: Ortino/Petersmann (note 22), at 217-262.

${ }^{113}$ On this dispute and other GATT practice relating to Article XXI see: Guide to GATT Law and Practice. Analytical Index, WTO 1995, at 600-608.

${ }^{114}$ See the case-study by Ambassador H. Paemen in: Petersmann/Pollack (note 24), 361-370.

${ }^{115}$ See the complaint by India mentioned in note 61 above. 
challenged in GATT or WTO dispute settlement proceedings the "political conditions" attached to the voluntary "Generalized System of Preferences" (GSP) granted by developed countries for LDCs. India carefully limited its successful WTO panel proceeding in 2003 against EC-Conditions for the Granting of Tariff Preferences to Developing Countries to the "drug arrangements" for combating drug production and drug trafficking in Pakistan, without challenging the "human rights conditionality" and "environmental conditionality" of the EC's GSP. Judicial deference towards policy discretion also explains the longstanding GATT and WTO jurisprudence that legislation authorizing future violations of WTO rules are presumed to be WTO-compatible as long as such violations are not mandated and remain a matter of discretion. ${ }^{116}$

d) International Disputes over Private Rights Should be Left to Domestic Courts and Transnational Arbitration

Most disputes over foreign trade restrictions, investments and intellectual property rights are settled through negotiations, recourse to domestic courts or "mixed" investor-state arbitration (e.g. pursuant to ICSID, UNICTRAL or NAFTA Chapter 11 rules). Almost 10\% of all WTO disputes refer to intellectual property claims based on the TRIPS Agreement. An increasing number of other WTO disputes involve claims that trade-related investment measures are inconsistent with the GATS rules protecting services suppliers, or with the WTO Agreement on TRIMS protecting foreign investors. ${ }^{117}$ While most WTO disputes challenge general legislative or regulatory measures, some of them relate to private commercial disputes among private companies, like the WTO dispute over the conflicting claims of EC and US competitors over the trademark "Havana Club". 118

Some of the more than 20 investor-state arbitration proceedings under Chapter 11 of NAFTA over private claims of compensation for "regulatory takings" have been widely criticized because of the one-sided "producer bias" of the relevant NAFTA rules in favor of privileged treatment of broadly defined investor rights based on the traditional international minimum standards for the protection of "aliens", the non-transparent arbitration proceedings, and their one-sided focus on private rights rather than public interests. ${ }^{119}$ Rather than politicizing and transforming disputes over private rights into intergovernmental WTO disputes with the possibility of welfare-reducing trade sanctions, governments should leave such disputes to domestic courts and to transparent international court proceedings based on nondiscriminatory rules, as it is done inside the EC where the EC Treaty "in no way prejudice(s) the rules in Member States governing the system of property ownership" (Article 295 EC Treaty). Since private property is protected in the national constitutional laws of all EC member states, and every EC member state also accepted the guarantees of private property in Protocol 1 to the European Convention on Human Rights, disputes over "regulatory takings"

${ }^{116}$ On the GATT and WTO jurisprudence that legislation mandating a violation of WTO obligations can be WTO-incompatible, whereas legislation that merely gives the executive discretion to violate those obligations may be WTO-compatible, see e.g.: S.Bhuiyan, Mandatory and Discretionary Legislation: The Continued Relevance of the Distinction under the WTO, in: Journal of International Economic Law 2002, 571-604.

${ }^{117}$ For a discussion of the so far 4 WTO disputes relating to the WTO Agreement on TRIMS see: M.Lara, The Agreement on Trade-Related Investment Measures, in: The Kluwer Companion to the World Trade Organization, 2004.

${ }^{118}$ See the WTO panel (WT/DS176/R )and Appellate Body reports (WT/DS176/AB/R) and the casestudy by F.Abbott/T.Cottier (supra note 64).

${ }^{119}$ Cf. e.g. Private Rights, Public Problems. A Guide to NAFTA's Controversial Chapter on Investors Rights, International Institute for Sustainable Development 2000. 
by EC member states are decided on the basis of non-discriminatory rules and transparent procedures in national courts subject to review by the European Court of Human Rights. Just as traders and investors from other EC member states are protected in a non-discriminatory manner by domestic courts inside the EC based on national and internationally agreed rules, disputes with traders and investors from other WTO member countries could be settled most effectively by domestic courts with due regard to the internationally agreed and democratically approved WTO rules.

e) Surveillance of Implementation of WTO Dispute Settlement Rulings May Lead to Political and Legal Follow-up Disputes

The adoption of dispute settlement findings by the WTO entails "recommendations" and/or legally binding "rulings" (cf. Article 21 DSU, GATT Article XXIII) that usually settle the legal dispute over the correct interpretation of WTO rules in the concrete dispute. This clarification of the "primary" legal rights and obligations of the WTO Members concerned does, however, not necessarily ensure a definitive "political settlement" of the dispute by means of compliance with the "secondary" WTO obligations "to secure the withdrawal of the measures concerned if these are found to be inconsistent with the provisions of any of the covered agreements" (Article 3:7 DSU). In the WTO disputes over EC import restrictions on bananas and hormone-fed beef, or over the US export subsidies for foreign sales corporations (FSCs), the WTO dispute settlement rulings were not implemented within the "reasonable period of time" (Article 21 DSU) and led to "follow-up disputes" over the WTO-consistency of the implementing measures and over the amount of countermeasures pursuant to Article 22 of the DSU. Even if the legal dispute settlement findings have been accepted at the international level, their domestic implementation (e.g. through changes of domestic legislation) may entail additional legal, political and economic disputes at home, for instance in the political efforts at getting a parliamentary majority for new legislation and at fending-off interest group claims for financial compensation. The DSU rules on "Surveillance of Implementation of Recommendations and Rulings" (Article 21 DSU), and on "Compensation and the Suspension of Concessions" (Article 22 DSU), recognize the different legal and political dimensions of such "follow-up disputes" by providing for recourse to arbitration procedures with short deadlines.

\section{INSTITUTIONALIZING ALTERNATIVE DISPUTE RESOLUTION (ADR) METHODS FOR CERTAIN KINDS OF WTO DISPUTES?}

In contrast to the frequent recourse to mediation and conciliation for the settlement of private international business disputes, Article 5 of the DSU on good offices, conciliation and mediation has been invoked in WTO practice only recently. Under GATT 1947, there had been only three cases in which the provisions on good offices, mediation and conciliation by the Director-General (e.g. in paragraph 8 of the 1979 GATT Understanding on Dispute Settlement) had been resorted to. ${ }^{120}$ All three cases involved complaints against developed countries. Two of these mediation efforts by the Director-General, or by his representative, were not successful (i.e. the mediation by the DG in the 1982 Citrus preferences dispute between the EC and the US, and the good offices by the DG in the first Banana dispute 1992 between developing countries and the EC). The very limited success of the mandatory conciliation phase in the

${ }^{120}$ For analyses of these cases - i.e. the disputes involving the EC and the US regarding EC tariff treatment of citrus products (1982), the EC and Japan concerning pricing and trading practices for copper in Japan (1987), and Canada and the EC concerning Article XXIV negotiations (1988) - see Raman (note 62). 
Subsidies Committee pursuant to the 1979 Tokyo Round Agreement on Subsidies has prompted WTO Members to refrain from making conciliation compulsory under the dispute settlement provisions of the WTO Agreement on Subsidies prior to submission of the dispute to a WTO panel.

In a communication dated 17 July 2001, the Director-General has notified WTO Members of his willingness to assist them in good offices, mediation and conciliation pursuant to Article 5.6 of the DSU, and emphasized the need for making Article 5 operational. ${ }^{121}$ The communication sets out detailed "Procedures for Requesting Action Pursuant to Article 5 of the DSU." For the first time in GATT and WTO dispute settlement practice, applicants are requested to specify the nature of their Article 5 demand in view of the legal differences between good offices, conciliation and mediation. ${ }^{122}$ As neither the Director-General nor his Deputy Director-General are trained mediation and conciliation experts, the procedures enable the Director-General to provide Secretariat staff and/or outside consultants to assist in the process and to ensure that such support staff has no direct involvement in the dispute in question either before or after the Article 5 procedure. The communication states that

“the Director-General does not expect to provide 'advisory opinions', strictly speaking, although informal non-legal advice regarding the best path to finding a solution may be appropriate. Legal conclusions regarding a particular dispute are best left to the formal dispute settlement process. Rather, Article 5 should be seen more as efforts to assist in reaching a mutually agreed solution. It should also be recalled that Article 25 provides for Arbitration and the Director-General does not wish to encroach upon this provision of the DSU."

Article 5 of the DSU was invoked for the first time in September 2002 in a joint request for mediation by the Philippines, Thailand and the EC. The purpose of the requested mediation process was "to examine the extent to which the legitimate interests of the Philippines and Thailand are being unduly impaired as a result of the implementation by the European Communities of the preferential tariff treatment for canned tuna originating in ACP states. In the event that the mediator concludes that undue impairment has in fact occurred, the mediator could consider means by which this situation may be addressed." ${ }^{\prime 23}$ In spring 2003, the EC accepted the - so far unpublished - mediation proposal and implemented it through an EC regulation.

The "Procedures for Requesting Action Pursuant to Article 5 of the DSU" - as attached to the Communication from the Director-General dated 17 July 2001 - do not deal with all the ADR techniques that are commonly used in private business law in order to avoid recourse to litigation in courts (such as "mini-trials"). In WTO law no less than in private business law, ADR methods and "forum choice" become increasingly important in certain kinds of disputes (e.g. involving trade-related intellectual property rights, private investment rights of "services suppliers", government procurement contracts) which may be submitted, alternatively or simultaneously, to domestic, regional or world-wide dispute settlement procedures in national or regional courts, transnational ICSID- or WIPO-arbitration, or intergovernmental WTO dispute settlement proceedings. The successful WTO mediation in 2002/2003 suggests that disputes over trade-distorting effects of trade preferences (e.g. under the GSP, customs unions and free trade areas) may be easier to settle through recourse to political third-party mediation

${ }^{121}$ See WT/DSB/25 of 17 July 2001.

${ }^{122}$ See WT/DSB/25, note 9: Good offices, conciliation and mediation are seen as three different levels of involvement of the Director-General with good offices being overseeing logistical and Secretariat support, conciliation involving direct participation in negotiations, and mediation including the possibility of actually proposing solutions, if appropriate. Flexibility is to be maintained with regard to changing the role.

${ }^{123} \mathrm{WT} / \mathrm{GC} / 66$ of 16 October 2002. 
in the WTO than through (quasi)judicial procedures, especially if the complainant appeals to the political discretion of preference-granting countries rather than - as in the case of India's complaint against the EC's tariff preferences for combatting drug production in Pakistan challenges the legal inconsistency of discriminatory tariff preferences with GATT Article I and the "Enabling Clause." 124

Why is it that - in private national and international commercial law but apparently not in public international law - ADR is being increasingly recognized as an important alternative to adversarial arbitration or court litigation whose higher costs, longer duration and sometimes less predictability (e.g. in case of juries and punitive damages) are viewed as less advantageous than ADR ${ }^{125}$ State practice in multilateral treaty relations with compulsory jurisdiction (such as WTO law) suggests that governments prefer to invoke and enforce their agreed rights; also in "private/public partnerships in WTO litigation"126, private economic operators may be reluctant to compromise the rule of law through ad hoc solutions to individual disputes that may undermine future legal predictability and legal certainty. The preconditions and potential advantages of ADR in private commercial relations (e.g. private control over the dispute, avoidance of long, unpredictable and costly court proceedings and jury verdicts) are very different from those in WTO dispute settlement proceedings that tend to be short, predictable and less costly than private arbitration. WTO dispute settlement proceedings are also likely to create precedents for the future interpretation of WTO rules in future disputes affecting other governments and private economic operators beyond the control of the parties to the dispute.

As in private business law, the interests of the economic operators affected by violations of WTO rules may not necessarily correspond to the self-interests of their legal attorneys, or to the diplomatic interests of their home governments. The legal remedies available in alternative fora may vary considerably (e.g. reparation of injury and financial compensation being available on the basis of general international law principles of state responsibility in ICJ- and ICSID-proceedings but not in WTO proceedings). Private producers, investors, importers, exporters and service suppliers may have good reasons to handle and control certain dispute settlement proceedings themselves (e.g. in domestic court proceedings or "mixed" international arbitration proceedings) rather than requesting their home government to take up their complaint in the WTO. The initiative by the WTO Director-General, in July 2001, for more effective mediation and conciliation procedures should not preclude further consideration of the usefulness of an "ADR Centre" financed by private industries (and complementing the Advisory Centre for WTO Law established in 2001) offering - for certain categories of disputes, like e.g. the "independent review procedures" pursuant to Article 4 of the WTO Agreement on Preshipment Inspection for disputes among pre-shipment inspection companies and exporters - early neutral evaluation, mini-trials and other ADR techniques by trained mediators.

\section{NEED FOR PROMOTING "COMITY" AMONG INTERNATIONAL TRIBUNALS AND JUDICIAL COOPERATION IN THE ENFORCEMENT OF RULE OF LAW}

The "legalization" of international trade relations and the proliferation of international courts have led to an increasing "judicialization" of dispute settlement in international

\footnotetext{
${ }^{124}$ See the panel report mentioned above in note 61.

${ }^{125}$ See e.g. the literature referred to in notes 57 and 63 above.

${ }^{126}$ Cf. Shaffer (note 21).
} 
relations. ${ }^{127}$ In addition to the increasing number of worldwide and regional courts and (quasi)judicial dispute settlement procedures (e.g. pursuant to regional and worldwide human rights conventions, trade and environmental agreements), individual access to justice has become recognized as a human right ${ }^{128}$ and contributes to the emergence of a "global community of courts". ${ }^{29}$ An increasing number of worldwide and regional trade agreements explicitly guarantee individual access to domestic courts and judicial remedies against illegal trade restrictions. If export industries, for example in the United States, want to challenge foreign trade restrictions, they may either petition the US government to initiate intergovernmental dispute settlement proceedings in worldwide or regional fora (e.g. in the WTO or pursuant to Chapter 20 of NAFTA), or they may initiate themselves judicial proceedings in foreign courts or regional courts (e.g. in the EC or EFTA Court of Justice, NAFTA panel proceedings pursuant to Chapter 19, mixed arbitration pursuant to Chapter 11 of NAFTA). Export industries in developing countries, by contrast, often lack the financial and "legal resources" for equivalent transnational or intergovernmental litigation strategies. ${ }^{130}$

The increasing number of international courts and (quasi)judicial procedures have been established independently on the basis of different treaties with different objectives and different constituencies. Hence, there is no formal hierarchy between the different international courts. For example, even though the ICJ has jurisdiction to adjudicate any legal dispute between states, UN member states remain free to submit their legal disputes to other international courts of general jurisdiction (like the Permanent Court of Arbitration) or of specialized jurisdiction (like the UN Law of the Sea Tribunal). ${ }^{131}$ Competing jurisdictions are also frequent for private international complaints, for example complaints based on regional or worldwide human rights instruments. ${ }^{132}$ Even after intergovernmental judicial proceedings have been initiated, alternative dispute resolution mechanisms remain important, as reflected in those ICJ judgments which call for further negotiations among the parties to the dispute, define the legal principles to be taken into account in such alternative dispute settlements, or otherwise induce the parties to reach a negotiated settlement. ${ }^{133}$

${ }^{127}$ Cf. the two recent symposia publications on: Emerging Fora for International Litigation, Harvard International Law Journal Winter 2003; Judicialization and Globalization of the Judiciary, Texas International Law Journal Special Issue 2003. Shany (note 15, at 5-7) lists more than twenty new international adjudicative mechanisms and (quasi) judicial procedures established since the mid-1980s.

${ }^{128}$ Cf. e.g. C.Harlow, Access to Justice as a Human Right, in: P.Alston et alii (eds), The EU and Human Rights, 1999, 187-214.

${ }^{129}$ Cf. A.M.Slaughter, A Global Community of Courts, Harvard International Law Journal 44 (2003), 201.

130 On the frequent lack, in developing countries, of the "legal infrastructure" for "private/public partnerships" in challenging foreign trade restrictions (e.g. domestic legislation similar to Section 301 of the US Trade Act or the EC's Trade Barriers Regulation for cooperation among the government agencies preparing a WTO dispute settlement proceeding and private economic interests) see G.Shaffer, How to Make the WTO Dispute Settlement System Work for Developing Countries: Some Proactive Developing Country Strategies, in: Towards a Development-Supportive Dispute Settlement System in the WTO, International Centre for Trade and Sustainable Development, 2003, 3-62.

${ }^{131}$ The non-exclusive jurisdiction of the ICJ is emphasized in Article 95 of the UN Charter: "Nothing in the present Charter shall prevent Members of the United Nations from entrusting the solution of their differences to other tribunals by virtue of agreements already in existence or which may be concluded in the future."

${ }^{132}$ According to Shany (note 15), at 8, "on some forty occasions human rights complaints have been lodged by the same individuals under more than one human rights mechanism". There have also been cases of overlapping jurisdiction between the UN Human Rights Committee and the ILO's Freedom of Association Committee since both Committees monitor freedom of association (cf. Shany, note 15, at 48-49). The ILO also had to deal with cases previously submitted to regional human rights procedures.

${ }^{133}$ For examples see the contributions in: C.Peck/R.S.Lee (eds.), Increasing the Effectiveness of the International Court of Justice, 1997, 324-369. 
The clauses for submission of disputes to the ICJ in the conventions on the protection of intellectual property rights administered by the WIPO, or in the Constitution of the International Labour Organization, have never been used for submitting such economic and social disputes to the ICJ. Whereas earlier Friendship, Commerce and Navigation treaties (e.g. of the USA) used to include compromissory clauses providing for the settlement of disputes by the ICJ, most modern BITs now provide for investor-state arbitration and inter-state arbitration rather than for ICJ jurisdiction. Regional economic integration law ${ }^{134}$ and WTO law (Article 23 of the DSU) often provide for an exclusive jurisdiction of their respective dispute settlement bodies if "Members seek the redress of a violation of obligations or other nullification or impairment of benefits under the covered agreements" (Article 23:1 DSU). Such exclusive jurisdiction clauses have, however, not prevented simultaneous or successive trade disputes in the WTO and in regional fora (e.g. the ECJ, NAFTA panels) scrutinizing the same governmental measures from different legal perspectives. According to Article 2005 of NAFTA,

"(s)ubject to paragraphs 2, 3 and 4, disputes regarding any matter arising under both this Agreement and the General Agreement on Tariffs and Trade, any agreement negotiated thereunder, or any successor agreement (GATT), may be settled in either forum at the discretion of the complaining Party."

Paragraph 6 of Article 2005 prescribes, however, that

"(o)nce dispute settlement procedures have been initiated under Article 2007 or dispute settlement proceedings have been initiated under the GATT, the forum selected shall be used to the exclusion of the other, unless a Party makes a request pursuant to paragraph 3 or 4" (i.e. the special dispute settlement procedures for disputes relating to environmental, sanitary, phytosanitary or standards-related measures).

Competing and overlapping jurisdictions for the resolution of the same legal dispute pose legal problems if they lead to conflicting judgments, legal insecurity, or waste of scarce legal and other resources in case of multiple litigation. In private national and international law, such problems are countered by legislative and judicial limitations of unilateral forum shopping (e.g. judicial disregard of forum selection agreements that are neither fair nor reasonable), of parallel proceedings (e.g. refusal of jurisdiction in case of lis alibi pendens) and of abuse of rights (e.g. electa una via principle). The lis alibi pendens rule prohibiting initiation of another judicial proceeding during a pending judicial proceeding on the same legal claims among the same parties, and the res judicata rule precluding relitigation of the final judgment of a competent tribunal, have been recognized by international courts as generally recognized principles of law and of "judicial comity" among courts in the exercise of their judicial function. ${ }^{135}$ The application of these private law rules on competing and overlapping jurisdictions by international courts in the field of public international law remains, however, rare and leaves open many questions. Some of these questions could be legally clarified in the cooperation agreements among the WTO and other international organizations with distinct dispute settlement procedures, like WIPO and ITU.

GATT and WTO dispute settlement panels were often requested to take into account the "precedential legal effects" of earlier GATT dispute settlement rulings, or of earlier GATT

${ }^{134}$ See e.g. Article 292 EC Treaty: "Member States undertake not to submit a dispute concerning the interpretation or application of this Treaty to any method of settlement other than those provided for therein." Similar exclusive jurisdiction provisions exist in the Andean Community and in the Central American Integration for the international courts set up by these agreements.

${ }^{135} \mathrm{Cf}$. Shany (note 15), 22-23, 279. The principle that "election of one forum" (electa una via) may preclude the plaintiff from submitting the same dispute among the same parties to another tribunal, is closely related to the lis alibi pendens rule. 
decisions (e.g. on the consistency of national balance-of-payments restrictions with GATT Article XVIII, and of preferential tariffs and other discriminatory preferential trade arrangements with GATT Article XXIV), when newly established dispute settlement panels had to examine the legality of the same government measures previously reviewed by other GATT bodies. A 1989 GATT panel had to examine, for a third time, complaints against EC import restrictions on apples and

"construed its terms of reference to mean that it was authorized to examine the matter referred to it by Chile in the light of all relevant provisions of the General Agreement and those related to its interpretation and implementation. It would take into account the 1980 Panel report and the legitimate expectations created by the adoption of this report, but also other circumstances of this complaint. The Panel, therefore, did not feel it was legally bound by all the details and legal reasoning of the 1980 Panel report" ..."While taking careful note of the earlier panel reports, the Panel did not consider they relieved it of the responsibility, under its terms of reference, to carry out its own thorough examination".... 136

In July 1985, the United States requested the GATT Council to apply the legal findings of a previously adopted panel report on "Japanese Measures on Imports of Leather" to quantitative restrictions on leather footwear maintained by Japan, since "the same administrative and legal scheme was used to restrict imports of leather footwear as was used for leather." Other GATT members expressed "reservations regarding the proposal that one panel's recommendations could be applied to another dispute; surely, only a panel could determine whether the cases in question were totally identical." The Council agreed to establish a new dispute settlement panel. ${ }^{137}$ The 1983 GATT panel report on "US imports of certain automotive spring assemblies" was adopted "on the understanding that this shall not foreclose future examination of the use of Section 337 (of the US Tariff Act of 1930) to deal with patent infringement cases from the point of view of consistency with Articles III and XX of the General Agreement."138 The 1989 GATT panel report on "US Section 337 of the Tariff Act of 1930" again examined complaints (this time by the EC) challenging the use of Section 337 in connection with patent enforcement and, contrary to the 1983 panel findings against Canada's similar complaints, found the discriminatory restrictions to be inconsistent with GATT Article III:4 and not "necessary" or otherwise justifiable under Article XX(d) of GATT. ${ }^{139}$

When, in March 1991, Brazil requested the GATT Council to establish a dispute settlement panel to examine the US denial of most-favored-nation treatment of non-rubber footwear imports from Brazil, the US objected on the ground "that this matter had already been adjudicated" in GATT in 1988 and "re-adjudication would violate the fundamental jurisprudential principle of res judicata - a final decision on a matter constituted an absolute bar to subsequent action thereon... the earlier Panel had taken all of Brazil's arguments into account in reaching its decision." The panel was established at the following GATT Council meeting in view of the fact that, inter alia, the 1988 panel proceeding had taken place under a separate agreement (the 1979 Tokyo Round Agreement on Subsidies), and the earlier panel report had not been adopted. ${ }^{140}$ Similar to this dispute settlement practice under GATT 1947, several WTO dispute settlement panels have clarified the extent to which earlier WTO decisions (e.g. on the consistency of balance of payments restrictions with GATT Article

\footnotetext{
${ }^{136}$ GATT Analytical Index: Guide to GATT Law and Practice, $6^{\text {th }}$ ed. 1994, at 703.

${ }^{137}$ GATT Council Minutes C/M/191, at 37-38.

${ }^{138} \mathrm{C} / \mathrm{M} / 168$, at 10 .

${ }^{139}$ Cf. GATT Basic Instruments and Selected Documents (BISD) $36^{\text {th }}$ Supplement, 345, 393-396.

${ }^{140}$ GATT Analytical Index (note 136), at 704.
} 
XVIII, the consistency of free trade area agreements with GATT Article XXIV) and dispute settlement rulings are to be taken into account by subsequent dispute settlement panels. ${ }^{141}$

There is hardly any GATT or WTO dispute settlement report that does not justify its application and interpretation of GATT/WTO rules by reference to legal, political or (quasi)judicial interpretations adopted in previous GATT/WTO practices. The mutual coordination of multiple dispute settlement rulings under the variety of GATT and WTO dispute settlement procedures evolves pragmatically case-by-case rather than by recourse to general WTO rules on forum shopping, parallel and successive proceedings. WTO dispute settlement reports apply general international law rules in the light of the jurisprudence of other international courts (notably the ICJ), or refer to treaties (e.g. on the protection of the environment) concluded among WTO Members outside the WTO, even though such "judicial comity" has so far hardly been shown by other international courts vis-à-vis WTO jurisprudence. Parallel proceedings before national and international courts are frequent in WTO dispute settlement practice; yet, in conformity with the jurisprudence of other tribunals, they are not perceived as jurisdictional conflicts because the complainants, legal claims and applicable law tend to differ.

\section{Conclusions: Jurisdictional Competition as Incentive for Judicial Cooperation and for Promotion of Rule-of-Law through Judicial Networks}

Businesses increasingly resort to new ways of resolving transnational disputes by international arbitration or mediation so as to limit the risks and costs of being involved in litigation in foreign courts that risk disregarding relevant international trade rules and commercial practices. ${ }^{142}$ This contribution has argued that the proliferation of dispute settlement fora also in public international economic law is, prima facie, a positive legal development reflecting an enhanced willingness of governments to strengthen the rule of international law in transnational relations. As the very broad scope of WTO law overlaps with numerous other international and regional agreements, cooperation among international and national courts becomes ever more important for maintaining rule of law, and for reducing transaction costs, in international relations among producers, investors, traders and consumers. Similar to the increasing resort to private international arbitration, intergovernmental "expeditious arbitration within the WTO as an alternative means of dispute settlement" (Article 25 DSU) could enable private parties and governments to broaden the "applicable law", and further improve the applicable procedures, for the settlement of international economic disputes in the WTO, with better regard to other relevant international economic rules (e.g. on intellectual property rights, investor rights, legal remedies, human rights, labor and social rights) than it might be possible in normal WTO panel proceedings or in arbitration proceedings outside the WTO.

The rule-oriented WTO dispute settlement system clearly mitigates power-disparities in international relations and helps governments to limit power politics also inside their countries (e.g. by limiting protectionist abuses of trade policy discretion in favor of rentseeking interest groups, by requiring independent judicial remedies inside countries like China which did not have such legal institutions prior to their WTO membership). The clarification of GATT and WTO rules through GATT and WTO dispute settlement findings is increasingly

${ }^{141}$ Cf. F. Roessler, The Institutional Balance between the Judicial and the Political Organs of the WTO, in: M.Bronckers/R.Quick (eds), New Directions in International Economic Law. Essays in Honor of John H. Jackson, 2000, 325-346.

${ }^{142}$ Cf. "Businesses adopt new ways of resolving disputes", Financial Times June 23, 2004, at 6 (mentioning a 25 per cent rise in demand for international arbitration in the past 5 years). 
influencing also multilateral WTO negotiations and, in some instances (such as the US-EC oilseeds dispute settlement findings leading to the 1992 Blair House Agreement), has been of crucial importance for the successful conclusion of trade agreements in GATT and the WTO. ${ }^{143}$ While the progressive clarification of international trade rules through WTO jurisprudence (such as the more than 35 WTO dispute settlement findings on antidumping rules, the more than 40 WTO dispute settlement interpretations of WTO subsidy rules) continues to be implemented in the administrative practices of WTO governments within a reasonable period of time, domestic legislatures and courts continue to be more reluctant to adjust domestic legislation and judicial practices to WTO jurisprudence.

The frequent legal inconsistencies between (quasi)judicial rulings of WTO dispute settlement bodies, regional trade courts (such as the EC Court and NAFTA panels) and domestic courts regarding the interpretation and application of international trade law confirm that - in international trade law no less than in other fields of public international law - national and international courts do not yet constitute a coherent legal and judicial system. Outside regional systems (like EC law, European human rights law and, to a lesser extent, NAFTA, MERCOSUR and the Andean common market), coordination and judicial cooperation among international courts, as well as among international and national courts, in order to avoid inconsistent decisions - even on the legality of the same government measures (such as the EC import restrictions on bananas) - remain rare. The inherent powers of courts to exercise comity towards, and cooperate with other tribunals in the maintenance of rule of law are rarely used among international courts. ${ }^{144}$ The proliferation of international dispute settlement fora, and the (sometimes explicit) admission (e.g. under NAFTA, Article 1 of the MERCOSUR Olivos Protocol, and under many bilateral free trade agreements) of free choice among competing jurisdictions, encourages forum shopping and "rules shopping" so as, e.g., to win a dispute in the WTO which might be lost in NAFTA, MERCOSUR or other regional dispute settlement proceedings among the same parties. ${ }^{145}$ Competition among different international courts does, however, not yet present a major problem in international trade. Whereas forum shopping and "rules shopping" in private international commercial law may seriously inconvenience private parties attacked against their will in distant foreign fora applying foreign law, respondent parties in intergovernmental litigation usually have the resources to defend themselves in international courts whose jurisdiction they have voluntarily accepted.

143 See the empirical evidence of the influence of GATT dispute settlement proceedings on the conclusion of the 1979 Tokyo Round and 1994 Uruguay Round Agreements, as well as of the influence of recent WTO dispute settlement proceedings (e.g. on cotton, dairy and sugar subsidies) on the Doha Development Round negotiations in the WTO, in: E.U.Petersmann, The End of the WTO's Peace Clause: Strategic Use of WTO Dispute Settlement Proceedings for Advancing WTO Negotiations on Agriculture, in: E.U.Petersmann (ed), Preparing the Doha Development Round: Developing Countries, Agricultural Trade, Services Trade, and Member-Driven Governance in the WTO, EUI 2004.

${ }^{144}$ Cf. F.Weiss, Inherent Powers of National and International Courts, in: Ortino/Petersmann (note 22), 177-190.

145 As NAFTA law permits choosing among NAFTA panels or WTO panels, NAFTA member states have so far resorted only to three panel proceedings pursuant to Chapter 20 of NAFTA and - notably in case of Canada and Mexico - prefer submitting disputes to the more "judicialized" WTO dispute settlement proceedings. Less-developed WTO members have more favourable rights under WTO dispute settlement proceedings (e.g. as regards differential treatment, legal assistance) than in many alternative regional dispute settlement fora (e.g. in case of complaints against the EC under the Cotonou Agreement). Whereas many free trade agreements (e.g. among Chile and Korea, Australia and US) reserve the option of submitting disputes over WTO rules to the WTO, some bilateral and multilateral free trade area agreements (including the current draft texts for a Free Trade Area of the Americas, FTAA) favour bilateral dispute settlement procedures that are favourable for countries with large "legal resources" (like the US) but risk to entail legal fragmentation. 
While the ICJ has been criticized for neglecting its "constitutional function" for the UN legal system in favor of a pragmatic "arbitration-like" resolution of many inter-state disputes ${ }^{146}$, the regular intervention by third parties in WTO and EC Court proceedings illustrates that - in regional and worldwide economic law - the "systemic" and "constitutional functions" of compulsory adjudication are well recognized by states. There are several reasons explaining such different judicial practices (e.g. regarding third-party intervention), such as the clearer focus of dispute settlement proceedings in the ICJ on "national interests" (such as national borders, war and peace), the mixture of private and public, bilateral and multilateral interests in many trade disputes (e.g. about trade discrimination), or the elaboration of international court procedures by states (e.g. in the case of the DSU) rather than by judges (e.g. regarding the internal procedures of the ICJ). Purely bilateral dispute settlement proceedings remain an exception in the WTO: about one third of WTO dispute settlement cases involve multiple complainants; and third parties intervene in more than $80 \%$ of all cases pursuant to Article 10 of the DSU.

Similar to the frequent criticism by EC member governments of the "judicial governance" and bold "constitutional jurisprudence" by the EC Court of Justice, the WTO Appellate Body has come under increasing criticism - not only by academics but also by WTO member governments - of "judicial activism" in the progressive development of WTO law leading to an institutional imbalance between the strong judicial branch and the much less efficient "legislative" and "executive branches" of the WTO. ${ }^{147}$ For example, when the WTO Appellate Body construed Articles 13 and 17 of the DSU as permitting unsolicited amicus curiae briefs by non-governmental organizations, a special meeting of the WTO's General Council was convened and expressed strong criticism:

"The Appellate Body had unfortunately ignored the overwhelming sentiment of Members against acceptance of unsolicited amicus curiae briefs. By introducing this additional procedure, which amounted to soliciting amicus curiae briefs from NGOs, the Appellate Body had indicated that it wanted to go one step further in total disregard of the views of the overwhelming majority of the WTO Membership."148

When the Appellate Body reports in Canada - Dairy (Article 21.5) were discussed in the WTO Dispute Settlement Body, many WTO Members criticized

"the new test that the Appellate Body has read into the Agreement on Agriculture for the purpose of determining whether a 'payment' existed under Article 9.1(c) ... Cost of production appeared nowhere in the text of the Agreement on Agriculture, nor was it clear why 'proper value', which itself was a term that did not appear in the Agreement on Agriculture, equated to cost of production ... It was odd that the WTO would not consider the market as being a good indicator of the value of goods." "The "Tinding of the Appellate Body clearly went beyond the ordinary meaning of the words in the Agreement on Agriculture... The Appellate Body had failed a fundamental obligation of the treaty interpreter... The

146 Cf. the contributions by P.M.Dupuy, The Danger of the Fragmentation or Unification of the International Legal System and the ICJ, as well as by E.U.Petersmann, Constitutionalism and International Adjudication: How to Constitutionalize the UN Dispute Settlement System?, to the symposium issue of the New York University Journal of International Law and Policy 31 (1999), at 753, 791.

${ }^{147}$ Cf. e.g. C.D.Ehlermann, Six Years on the Bench of the "World Trade Court", in: Ortino/Petersmann (note 22), 499, 523-530.

${ }^{148}$ WTO document WT/GC/M/60 (statement by the representative of India).

$149 \mathrm{WT} / \mathrm{DSB} / \mathrm{M} / 116$, at 70 (statement by the representative of the United States). The panel finding, which had used both domestic market prices as well as world market prices as benchmarks for determining "payments in kind", had been reversed by the Appellate Body without any convincing arguments. 
Appellate Body had clearly gone beyond what WTO Members agreed in the Uruguay Round negotiations." 150

In contrast to the cases where inter-state disputes capable of being referred to the ICJ were instead submitted to ad hoc arbitration ${ }^{151}$, WTO Members have not yet resorted to mutually agreed arbitration as an alternative to WTO panel or appellate proceedings. ${ }^{152}$ The legitimacy and limited legal remedies of WTO jurisprudence will, nonetheless, remain under challenge. For example, many of the "human rights cases" in the EC Court of Justice could similarly arise in the WTO, for instance if freedom of trade (e.g. Article XI:1 GATT) or freedom of transit (Article V GATT) are restricted in order to protect the human rights of demonstrators blocking motorways ${ }^{153}$, of consumers objecting to genetically modified food ${ }^{154}$, or of scientists using their freedom of speech for criticizing the dangers of microwave ovens. ${ }^{155}$ There is not a single GATT or WTO panel, appellate or arbitration report whose legal findings have, in the past, referred to the human rights obligations of WTO Members. Just as the EC Court has occasionally avoided to rule on the human rights dimensions of trade disputes ${ }^{156}$, so do WTO dispute settlement bodies prefer to avoid making findings on the human rights dimensions of WTO disputes. Even though the numerous "general exceptions" in WTO Agreements (such as GATT Article XX,a permitting "measures necessary to protect public morals") offer ample legal possibilities for justifying trade restrictions in order to protect human rights ${ }^{157}$, WTO panels lack legal expertise in the field of human rights and have never clarified how WTO obligations should be "balanced" and reconciled with the human rights obligations of WTO Members. WTO panels are also reticent to apply "constitutional approaches" balancing international trade, environmental and other treaty obligations on the basis of generally recognized constitutional principles, such as non-discrimination, necessity, proportionality, due process of law, transparency and human rights. ${ }^{158}$ Yet, legal complaints in human rights bodies against legal decisions of WTO bodies remain unlikely: Just as the European Commission on Human Rights declined jurisdiction to review alleged human rights violations in EC Court proceedings ${ }^{159}$, UN human rights bodies are unlikely to assert jurisdiction over claims that WTO dispute settlement bodies have disregarded UN human rights instruments.

${ }^{150} \mathrm{WT} / \mathrm{DSB} / \mathrm{M} / 141$, at 4 (statement by the representative of Canada).

151 See e.g. the Southern Bluefin Tuna Arbitration Award (Australia and New Zealand v. Japan) of 4 August 2000 (39 ILM 2000, 1359) where the ICJ could have been seized based on the optional clause declarations of all three states involved.

${ }^{152}$ See, however, Brazil's WTO complaint against Argentina's safeguard restrictions on cotton imports (WT/DS190, settled by the parties), where a related part of the complaint was decided by ad hoc arbitration in MERCOSUR (cf. Shany, note 15, at 59).

${ }^{153}$ See ECJ Case C-112/200, Schmidberger, in note 34 above.

${ }^{154}$ See ECJ Case C-377/98, Netherlands v. European Parliament and Council, in note 31 above.

155 See the Hertel case before the European Court of Human Rights, note 35 above.

${ }^{156}$ Cf. Case C-159/90, Society for the Protection of Unborn Children in Ireland v. Grogan, ECR 1991 I, 4685 (the Court held that the Irish advertising ban against a student organization distributing information on foreign abortion services was not covered by EC law).

${ }^{157}$ Cf. E.U.Petersmann, Human Rights and the Law of the WTO, in: Journal of World Trade 2003, 242281.

${ }^{158}$ On the comprehensive WTO jurisprudence on the WTO treaty requirements of non-discrimination and necessity see, e.g., J.Neumann/E.Türk, Necessity Revisited: Proportionality in World Trade Organization Law After Korea-Beef, EC-Asbestos and EC-Sardines. In: Journal of World Trade 2003, 199-233.

${ }^{159}$ Cf. Melchers \& Co. v. Germany, Appl. 13258/87, 1990 Yearbook Eur. Conv. on Human Rights 138). This refusal of ratione materiae jurisdiction of the European Commission on Human Rights was based on the ECJ jurisdiction to examine the consistency of EC law with the human rights guaranteed in the European Convention on Human Rights, and on the lack of EC membership in the ECHR. 
Similar to the increasing number of human rights complaints that have been lodged by the same individuals under more than one regional or worldwide human rights instrument ${ }^{160}$, the number of judicial challenges in national, regional and worldwide fora of the same governmental trade restrictions (e.g. on bananas) is likely to increase in the future. For instance, the refusal by several EC member governments to approve genetically modified organisms (GMOs) and to implement the 2002 EC Directive on the public release of GMOs is currently being challenged in the WTO (by Canada and the US), in the EC Court of Justice (e.g. by the EU Commission) as well as in national courts (e.g. by the private applicants and patent holders). Concurrent jurisdictions of, forum shopping among, and parallel litigation in national, regional and worldwide fora risk leading to incompatible judgments and fragmentation of the law if judges fail to construe national and regional trade law in conformity with the self-imposed WTO obligations of WTO member states, or without taking into account international agreements concluded among WTO Members outside the WTO (e.g. the rules on GMOs in the Cartagena Protocol to the UN Convention on Biodiversity). Prevention and settlement of disputes in international relations may increasingly fail if international courts rely exclusively on state-centered rules and disregard the private rights of transnational actors.

The few general international law rules limiting parallel or successive disputes among the same parties leave open many questions. For instance, the lis alibi pendens prohibition of commencing another judicial proceeding during the pendency of the same dispute in a different judicial body does not apply to courts of different national, regional and worldwide legal systems unless such a prohibition has been explicitly provided for (as e.g. in Article 2005:6 of NAFTA). The same seems to be true of the res judicata requirement that the parties to a dispute must respect the final judgment of a competent court: the EC Court of Justice, for example, has often ignored GATT and WTO dispute settlement rulings on the illegality of the same trade restrictions that were challenged before the EC Court after GATT or WTO dispute settlement findings had established their illegality. ${ }^{161}$ The frequent parallelism among national and regional court proceedings and GATT/WTO dispute settlement proceedings confirms that, contrary to the "principle of election" (electa una via) limiting multiple litigation by the same parties, seizing a domestic court by a private party does not preclude a state party from challenging a foreign governmental measure in intergovernmental dispute settlement proceedings, even if the intergovernmental dispute has been initiated by the same private party which has challenged the same government measure in a pending domestic court proceeding. Even though courts strive for legal and judicial consistency of their own jurisprudence, neither WTO nor EC and NAFTA dispute settlement bodies apply a stare decisis doctrine requiring strict application of judicial rulings in one case in similar future cases among different parties.

Human rights courts, European courts and WTO dispute settlement bodies are characterized by high levels of judicial review compared to state-centered international courts that are often more reluctant to challenge state sovereignty and foreign policy discretion. Competing jurisdiction among national and international trade courts, and academic criticism of introverted domestic judgments disregarding the WTO obligations of the country concerned, are likely to further improve the quality and overall consistency of judicial reasoning. There is

${ }^{160}$ Cf Shany (note 15), at 60, refers to 40 human rights complaints that have been brought before both global and regional complaints procedures.

${ }^{161}$ Cf. G.A.Zonnekeyn, EC Liability for the Non-Implementation of WTO Dispute Settlement Decisions, in: JIEL 6 (2003), 761-770; N. van den Broek, Legal Persuasion, Political Realism and Legitimacy: The European Court's Recent Treatment of the Effect of WTO Agreements in the EC Legal Order, in: 4 JIEL (2001), 411-440. In Cases C-93/02P and C-94/02P, Biret International SA v. Council, judgment of 30 September 2003 (nyr), the Court has left open the possibility of individuals invoking WTO obligations of the EC that have been formally established in WTO dispute settlement rulings and have not been implemented by the EC within the "reasonable period of time" prescribed by WTO law. 
also a case for using the cooperation agreements among the WTO and other intergovernmental organizations for promoting coordination and cooperation among their respective dispute settlement procedures. While the coordination of competing jurisdictions among international courts may be left to judicial practice, the need for interpreting domestic and international trade rules in a more coherent manner requires explicit, reciprocal recognition among trading countries (as e.g. in Article XX of the WTO Agreement on Government Procurement). It is only after domestic and international trade law have been recognized as constituting a coherent legal system for the benefit of domestic consumers and of other "market citizens", that a more coherent legal and judicial system - based on mutually consistent interpretation of national, regional and worldwide trade rules, cooperation among national and international judges, comity for their respective jurisprudence, decentralized judicial enforcement of nondiscriminatory and precise trade rules and respect for human rights - is likely to emerge. As long as intergovernmental rules (e.g. of WTO law) and non-transparent, intergovernmental dispute settlement proceedings (e.g. in the WTO) are viewed with democratic distrust by national legislatures (such as the US Congress) and by civil society, and domestic industries continue to perceive intergovernmental organizations in a mercantilist way as Machiavellian arenas for opening-up foreign markets (rather than for promoting productivity, open markets, more efficient and less discriminatory policies at home), the needed international cooperation among national and international courts for strengthening the rule of international law will remain difficult to secure.- 